\author{
Natalia Aleksiun \\ Touro College, Graduate School of Jewish Studies, Nowy Jork \\ https://orcid.org/0000-0001-7712-4878 \\ natalia.aleksiun@touro.edu
}

\title{
Gdy Fajga porzuciła Tadeusza. Wojenne związki ocalałych po Zagładzie
}

\begin{abstract}
Streszczenie
Analiza powojennej korespondencji Fajgi Ginsburg, polskiej Żydówki, która przeżyła Zagładę we Lwowie, z Tadeuszem Kobyłką - Polakiem ukrywającym ją i jej siostrzenicę - stanowi punkt wyjścia rozważań na temat powojennych intymnych dylematów. Losy tego związku są przykładem podejmowanych przez ocalałych decyzji o ich tożsamości. Listy Fajgi wyrażają emocjonalną traumę Żydów, którzy przeżyli Holokaust. Ukazują również skutki powojennych wyborów w życiu ocalałych i ludzi pomagających im pod niemiecką okupacją. Ujawniają też, jak odmienne były wizje związku i rozstania w oczach Fajgi i Tadeusza. Różnica wynikała częściowo z adresowania korespondencji do innych odbiorców: Fajga pisała osobiste listy do męża, podczas gdy listy Tadeusza trafiały do rozmaitych instytucji żydowskich i polskich i miały bardziej oficjalny charakter. W listach Tadeusza wyraźnie wybrzmiewa jego gniew na „Żydów”, których obwiniał za rozpad swojej rodziny, ale przenika je również poczucie zagrożenia powojennym antysemityzmem w Polsce, gdyż po wyjeździe Fajgi sam go doświadczał. Chociaż wymiana korespondencji między Fajgą a Tadeuszem jest pełna niedopowiedzeń, obala stereotypy „nacjonalistycznego Polaka” i „świadomego siebie Żyda”. Obie te kategorie okazują się zbytnim uproszczeniem, które nie oddaje złożoności relacji, zwłaszcza tej zainicjowanej podczas Zagłady.
\end{abstract}

\section{Słowa kluczowe}

aryjskie papiery, barter seksualny, gender, racjonalne związki, Sprawiedliwy wśród Narodów Świata

\footnotetext{
Abstract

This article examines the post-war correspondence between Fajga Ginsburg, a Polish Jewish woman who survived the Holocaust in Lwów (today Lviv in Ukraine), and Tadeusz Kobyłko - a Pole who hid her and her niece. Their letters offer a window into intimate dilemmas in the aftermath of the war. Their relationship exemplifies decisions made by survivors with regard to their identity. Fajga's letters express the emotional trauma of Jews who survived the Holocaust and show the lasting effects of post-war choices made by the survivors. Her letters also reveal how differently Faiga and Tadeusz understood their relationship and subsequent separation, in part due to their addressing different audiences whilst writing. While Fajga wrote personal letters to her husband, Tadeusz's letters were sent to various Jewish and Polish institutions and were more official in nature. His letters clearly echoed his anger at the "Jews" whom he blamed for the breakdown of his family, but they are also permeated by
} 
a sense of threat of post-war antisemitism in Poland, as he himself experienced it after Fajga's departure. Although the exchange of letters between Fajga and Tadeusz is full of understatements, it refutes the stereotypes of a "nationalist Pole" and a "self-conscious Jew". Indeed, both categories turn out to be an oversimplification that does not reflect the complexity of the relationship, especially the one initiated under the duress of the Holocaust.

\section{Key words}

Aryan papers, sexual barter, gender, rational relationships, Righteous among the Nations

Fajga (Fani, Fanka) Ginsburg (Ginsberg, Ginzberg) przeżyła Zagładę we Lwowie dzięki pomocy Tadeusza Kobyłki ${ }^{1}$. Ukrywając się po tzw. aryjskiej stronie, nie tylko podawała się za katoliczkę i żonę Tadeusza, lecz także związała się z nim i urodziła mu syna, który został ochrzczony i zapisany w księgach parafialnych jako Adam Kobyłko. Po wyzwoleniu Lwowa w sierpniu 1944 r. Kobyłkowie zarejestrowali się jako małżeństwo, a następnie przyjechali do Bytomia jako repatrianci. Już w sierpniu 1946 r. Fajga opuściła jednak męża, zabierając ze sobą dwoje małych dzieci: ich syna i jej siostrzenicę Itę (Ittę) Keller, którą Kobyłko również ukrywał w czasie wojny ${ }^{2}$. Przez kilka miesięcy, w drodze przez Czechosłowację do Francji, Fajga korespondowała z pozostawionym w Polsce mężem ${ }^{3}$. Jesienią 1947 r. dotarła z dziećmi do Palestyny, gdzie już wcześniej osiedliła się część jej rodziny4. Fajga i Tadeusz nigdy więcej się nie spotkali ${ }^{5}$.

${ }^{1}$ Dłuższa wersja niniejszego artykułu ukaże się w „Dubnow Yearbook” 2019, pod redakcją Elizabeth Gallas i Katy Bohus. Chciałabym podziękować za lekturę i cenne uwagi: Judy Baumel-Schwartz, Annie Bikont, Emily Gioielli, Annie Hájkovej, Natalii Judzińskiej, Agnieszce Ilwickiej-Karunie, Kamilowi Kijkowi, Jeffreyowi Kopsteinowi, Magdalenie Kozłowskiej, Laurze Levitt, Ruth Lichtenstein, Joannie Śliwie, Joannie Tokarskiej-Bakir, Raphaelowi Utzowi i Hannah Wilson. Z listami Fajgi i Tadeusza zetknęłam się w 2012 r., prowadząc badania jako Pearl Resnick Postdoctoral Fellow w The Center for Advanced Holocaust Studies, United States Holocaust Memorial Museum (USHMM) w Waszyngtonie. Vincent Slatt pomógł mi uzyskać dostęp do materiału.

${ }^{2}$ Zob. Itta Keller, Stary Sambor and Lviv, Ukraine, http://missing-identity.net/itta-kellerstary-sambor-and-lviv-ukraine (dostęp 1 XII 2020 r.).

${ }^{3}$ Zob. USHMM, Itta Keller Ben-Haiem Collection, 2007.129.1, Potwierdzenie przybycia do Palestyny wydane Icie Ginsburg przez Agencję Żydowską, Wydział Imigracji, 25 VII 1956 r.

${ }^{4}$ Ibidem, Potwierdzenie wydane przez Wydział Imigracyjny Agencji Żydowskiej w Jerozolimie, wystawione Icie Ginsburg 25 VII 1956 r. W dokumencie tym odnotowano, że Ita Ginsburg wylądowała w Hajfie 29 X 1947 r. Kobyłko podał zaś, że jego rodzina przybyła do Palestyny 20 XI 1947 r. (ibidem, Opis ciągłości wydarzeń).

${ }^{5}$ Fajga mieszkała przez wiele lat w niewielkim mieszkaniu w Tel Awiwie, pracowała w hotelowej kuchni. Wyszła za mąż za wdowca i opiekowała się nim do jego śmierci. Później mieszkała w Ramat Ganie z owdowiałą szwagierką męża. Nie chciała rozmawiać o swoich doświadczeniach w czasie okupacji ani o Tadeuszu Kobyłce. Umarła w 1991 r. Tadeusz ożenił się i doczekał trojga dzieci. W 1976 r. zginął w wypadku. Wdowa i część jego rodziny wyjechała do Niemiec. Jego dzieci urodzone po wojnie wiedziały o istnieniu wojennej rodziny i roli ojca. Po przyjeździe do Palestyny w październiku 1947 r. Ita spędziła dzieciństwo w domu 
Jak wielu ocalałych z Zagłady Fajga podjęła decyzję o powrocie do przedwojennej tożsamości i wyjechała z Polski. Wybory podejmowane przez członków społeczności żydowskiej po Zagładzie były pełne sprzeczności: z jednej strony odczuwali oni radość, że doczekali końca wojny, a z drugiej przeżywali żałobę po stracie rodziny, przyjaciół i całego żydowskiego środowiska. Jako Żydzi nie czuli się w powojennej Polsce bezpieczni. Mimo to ocalali zaangażowali się w odbudowę rodzin i różnorakich instytucji. Decyzja Fajgi o opuszczeniu Polski wydaje się współgrać z powszechną reakcją ocalałych na pogrom w Kielcach w lipcu 1946 r., który wywołał masową emigrację Żydów z kraju'6. Jej decyzja odzwierciedla również pragnienie wielu z nich, by odbudować życie z dala od rodzinnych miejscowości, gdyż znajome okolice przypominały im o zamordowanych krewnych i sąsiadach ${ }^{7}$. Lektura listów Fajgi i Tadeusza wskazuje jednak na bardziej złożoną tkankę emocjonalną ich małżeństwa, które prawdopodobnie rozpoczęło się pod niemiecką okupacją jako związek pragmatyczny. Powojenny etap tego związku obejmował zalegalizowanie ich małżeństwa we Lwowie po wejściu Armii Czerwonej, repatriację i wspólne życie w Bytomiu. Coraz bardziej świadomi, że ich rozłąka nie będzie tymczasowa, Fajga i Tadeusz próbowali zrozumieć wzajemne zależności i uczucia, jakie wobec siebie żywili. Jak odbierała ich związek Fajga, co myślała na temat głębokich więzi, które połączyły ją z Tadeuszem, kiedy walczyła o przetrwanie? Tak jak wielu ocalałych - kobiet

dziecka w okolicach Jerozolimy. Studiowała pedagogikę w Uniwersytecie Hebrajskim w Jerozolimie i na Sorbonie w Paryżu. Przez wiele lat pracowała w dziedzinie edukacji. Wyszła za mąż za Davida, urodziła czworo dzieci, została babcią. Kiedy w końcu lat osiemdziesiątych zaczęła szukać informacji na temat Tadeusza, odnalazła jego rodzinę w Niemczech. Po śmierci Fajgi podjęła starania o przyznanie Tadeuszowi tytułu Sprawiedliwego wśród Narodów Świata. W 2007 r. przekazała zebrane materiały do United States Holocaust Memorial Museum w Waszyngtonie. Zmarła w 2019 r. Adam również wychował się w domu dziecka. Przez lata borykał się z problemami zdrowotnymi. Na temat losów Itty w Izraelu zob. Itta Benhaiem Keller, U-welibi homa [hebr. Mur w moim sercu], Jeruszalaim: Yad Vashem, 2009. Dziękuję Oferowi Dynesowi i Marcie Marzańskiej-Mishani za pomoc w znalezieniu książki w czasie pandemii.

${ }^{6} \mathrm{Na}$ temat pogromu kieleckiego zob. Joanna Tokarska-Bakir, Pod klq̨twq. Społeczny portret pogromu kieleckiego, t. 1-2, Warszawa: Czarna Owca, 2018. Na temat powojennej przemocy antysemickiej zob. Jan Tomasz Gross, Strach. Antysemityzm w Polsce tuż po wojnie. Historia moralnej zapaści, Kraków: Znak, 2008; Anna Cichopek-Gajraj, Beyond Violence. Jewish Survivors in Poland and Slovakia, 1944-1948, Cambridge: Cambridge University Press, 2014.

${ }^{7} \mathrm{Na}$ temat różnych wizji odbudowy życia żydowskiego po Zagładzie zob. Natalia Aleksiun, Dokq̨d dalej? Ruch syjonistyczny w Polsce 1944-1950, Warszawa: Trio, 2002; Avinoam Patt, Finding Home and Homeland. Jewish Youth and Zionism in the Aftermath of the Holocaust, Detroit, MI: Wayne State University Press, 2009; Hana Shlomi, The Communist Caucus in the Central Committee of Jews in Poland, November 1944-February 1947, „Gal-Ed. On the History of the Jews in Poland" 1993, nr 13, s. 81-100; Bożena Szaynok, Bund i komuniści żydowscy w Polsce po 1945 r. [w:] Bund. 100 lat historii 1897-1997, red. Feliks Tych, Jürgen Hensel, Warszawa: Volumen, 2000, s. 305-324; David Slucki, The International Jewish Labor Bund after 1945. Toward a Global History, New Brunswick, NJ: Rutgers University Press, 2012. 


\section{Studia}

i mężczyzn - po wojnie stanęła przed wyborem: pozostać w związku zrodzonym w cieniu Zagłady czy się rozstać ${ }^{8}$.

Próba rekonstrukcji doświadczeń Fajgi i Tadeusza pozwala przez pryzmat historii uczuć przyjrzeć się doświadczeniu ocalałych z Zagłady i ich wyborom, szczególnie wyborom tych kobiet i mężczyzn, którzy w czasie wojny żyli na aryjskich papierach. W artykule staram się odpowiedzieć na pytanie o cenę, jaką płacili ocalali za powrót do żydowskiej tożsamości, i reakcję na to ich nieżydowskiego otoczenia. W jaki sposób mówili o związkach zawartych w czasie okupacji, a jakie aspekty tych relacji pomijali? Jaką rolę odgrywały żydowskie otoczenie, kontakty z pozostałymi przy życiu członkami ich rodzin? Kluczowe znaczenie w analizie związku Fajgi i Tadeusza mają perspektywa genderowa oraz zagadnienie sprawczości żydowskiej zarówno w czasie wojny, jak i po jej zakończeniu.

W artykule zgłębiam skomplikowane następstwa pragmatycznych relacji wojennych, wychodząc poza analizę losu ocalałych dzieci żydowskich, które tuż po wojnie pozostawały w nieżydowskich rodzinach i instytucjach ${ }^{9}$. W ostatnich latach historycy coraz częściej zwracają uwagę na racjonalne związki z nie-Żydami jako część żydowskich strategii przetrwania. Wskazują, że zarówno kobiety, jak i mężczyźni po aryjskiej stronie mogli poszukiwać intymnych relacji z nie-Żydami, licząc, że dzięki temu uda im się przeżyć ${ }^{10}$. Niekiedy Polacy i Polki nieżydowskiego pochodzenia proponowali małżeństwo żydowskim partnerom,

${ }^{8}$ Badania na temat zmieniających się po Zagładzie konstelacji rodzinnych dotyczą przede wszystkim małżeństw zawartych jeszcze przed wojną. Zob. Katharina Friedla, Strategie przetrwania i udzielanie pomocy żydowskim partnerom w małżeństwach mieszanych we Wrocławiu i Hamburgu. Studium kilku przypadków, „Zagłada Żydów. Studia i Materiały” 2015, nr 11, s. 310-324.

${ }^{9}$ Zob. Joanna B. Michlic, Piętno Zagłady. Wojenna i powojenna historia oraz pamięć żydowskich dzieci ocalałych w Polsce, Warszawa: Żydowski Instytut Historyczny, 2020; idem, "The War Began for Me after the War." Jewish Children in Poland, 1945-49 [w:] The Routledge History of the Holocaust, red. Jonathan C. Friedman, London: Routledge, 2011, s. 482-497; Emunah Nachmany-Gafny, Dividing Hearts. The Removal of Jewish Children from Gentile Families in Poland in the Immediate Post-Holocaust Years, Jerusalem: Yad Vashem, 2009; Nahum Bogner, At the Mercy of Strangers. The Rescue of Jewish Children with Assumed Identities in Poland, Jerusalem: Yad Vashem, 2009; Boaz Cohen, Survivor Caregivers and Child Survivors. Rebuilding Lives and the Home in the Postwar Period, „Holocaust and Genocide Studies” 2018, t. 32, nr 1, s. $49-65$.

${ }^{10} \mathrm{O}$ zjawisku tym w odniesieniu do Żydów niemieckich zob. Marion A. Kaplan, Between Dignity and Despair. Jewish Life in Nazi Germany, New York-Oxford: Oxford University Press, 1998; Susanna Schrafstetter, Flucht und Versteck. Untergetauchte Juden in München. Verfolgungserfahrung und Nachkriegsalltag, Göttingen: Wallstein, 2015; Beate Meyer, „Jüdische Mischlinge". Rassenpolitik und Verfolgungserfahrung 1933-1945, Hamburg: Dölling und Galitz Verlag, 1999. Zob. również Raphael Utz, Making Love and Make-Belief: Male Sexual Barter in Dov Freiberg's “To Survive Sobibor”, „Autobiografia. Literatura, kultura, media” 2010, nr 1 (14), s. 75-92; Katya Gusarov, Sexual Barter and Jewish Women's Efforts to Save Their Lives. Accounts from the Righteous among the Nations Archives, „German History”, 25 V 2020, https://doi. org/10.1093/gerhis/ghaa034. 
by ocalić im życie ${ }^{11}$. Mimo że Żydzi w tych związkach nie mieli statusu równoważnego partnera, nie byli całkowicie pozbawieni sprawczości. Co więcej, niektóre z tych relacji - jak związek Fajgi i Tadeusza - po wojnie przekształciły się w sformalizowane więzi rodzinne. Wiele lat po wojnie relacje Tadeusza z Fajgą i Itą oraz jego synem Adamem - Żydami, których ukrywał w okupowanym Lwowie - wpływały na życie jego i jego rodziny.

\section{Doświadczenie intymności}

W zeznaniach wielu ocalałych odnajdujemy intymne wspomnienia dotyczące wojennych związków i konfiguracji emocjonalnych, jakich doświadczyli. Duża część relacji pozostawia elementy tych doświadczeń w domyśle, nie zostają również dopowiedziane relacje o charakterze barteru seksualnego, związki pragmatyczne, a także romantyczne więzi łączące Żydów z nie-Żydami. Zapewne wielu ocalałych mężczyzn i wiele kobiet nie chciało zbyt obszernie opisywać sytuacji, które wiązały się z zależnością, ograniczoną sprawczością i często stanowiły tabu w warunkach odbudowywania powojennej normalności. W wypadku Fajgi Ginsburg i Tadeusza Kobyłki istnieje jednak obszerna dokumentacja w postaci zbioru listów Fajgi do Tadeusza, wysyłanych przez nią od jesieni 1946 do zimy 1947 r. Kobieta opowiadała w nich o życiu po wyjeździe z Polski, o lękach i nadziejach związanych z przyszłością, którą miała nadzieję zbudować dla siebie i dzieci. Próbowała również wyjaśnić Tadeuszowi swoje uczucia, podsumować niejako ich związek. Oprócz jej listów zachowały się też kopie oficjalnej korespondencji Tadeusza z różnymi instytucjami i organizacjami w Polsce i za granicą, w której starał się opowiedzieć własną historię, uzyskać pomoc w odnalezieniu swojej żydowskiej żony i dzieci, poskarżyć na krzywdę, która go spotkała' ${ }^{12}$. Brakuje natomiast osobistych listów Tadeusza do Fajgi. Dlatego możemy tylko domniemywać na podstawie reakcji Fajgi oraz prowadzonej przez niego oficjalnej korespondencji, jak on sam odbierał ich związek oraz rozstanie. Mimo tej luki i wiążącego się z nią metodologicznego wyzwania zebrany materiał pozwala podjąć próbę analizy złożonej relacji, na którą składały się z jednej strony wdzięczność i przywiązanie, z drugiej zaś dojmująca świadomość zależności, rozczarowanie, zgorzknienie, złość i poczucie zdrady. Nic dziwnego, że wojenna i powojenna historia tego związku jest pełna niejednoznaczności. Na przykład podpisując listy do Tadeusza, Fajga czasami posługiwała się polskim imieniem, które przyjęła, ukrywając się jako katoliczka - żona Kobyłki (Maria, Manusia),

${ }^{11}$ Najnowsze badania na temat Sprawiedliwych w Polsce skupiają się przede wszystkim na ich heroizmie. Do ważnych wyjątków należy książka Anny Bikont Sendlerowa. W ukryciu (Wołowiec: Czarne, 2017).

${ }^{12}$ USHMM, Itta Keller Ben-Haiem Collection, 2007.129.1; Archiwum Żydowskiego Instytutu Historycznego (dalej AŻIH), 301/6612, Relacja Tadeusza Kobyłki; Archiwum Yad Vashem (dalej AYV), M.31.2/5604, Righteous among the Nations. 


\section{Studia}

a innym razem inicjałami swojego żydowskiego imienia lub jego zdrobnieniem $\left(\right.$ Fanka) ${ }^{13}$.

W listach pisanych w drodze do Palestyny Fajga nawiązywała tylko do okupacyjnych wspomnień, zależności od męża i konfliktów towarzyszących ich wzajemnym relacjom. Po jej wyjeździe Tadeusz czuł się coraz bardziej wykluczony, boleśnie przeżywał rozłąkę z synem. Zarazem coraz bardziej utwierdzał się w przekonaniu, że Fajga złamała nieformalną umowę między małżonkami, gdyż mieli zaczać wspólne życie na emigracji. W rozpaczy i poczuciu bezradności sugerował wielokrotnie, że za wyjazdem jego rodziny stał "międzynarodowy spisek żydowski". Podczas gdy listy Fajgi były pojednawcze, choć też pełne niepewności, a czasem goryczy, zarazem jednak zalotne, listy Tadeusza przepełniało poczucie osobistej krzywdy porzuconego męża, ojca, któremu odebrano syna, i człowieka, który spodziewał się, że będzie mógł wyjechać z Polski i połączyć się z rodziną.

W latach 1946-1973 Kobyłko pisał do żydowskich i nieżydowskich instytucji, przedstawiając swoją rolę w uratowaniu Fajgi. Liczył na uzyskanie poparcia dla podjętych przez siebie starań zarówno w Polsce, jak i w Izraelu. Początkowo miał nadzieję, że jego rola w uratowaniu żony i opieka nad dwojgiem żydowskich dzieci pomoże mu w powojennej Polsce, że wyjedzie za granicę, i że znajdzie Fajgę w Izraelu ${ }^{14}$. Później starał się zdobyć wsparcie i uznanie moralne. Listy Kobyłki rzucają światło na to, jak konstruował swoją opowieść o tym, co wydarzyło się między nim a Fajgą. Dowodzą zarazem, jak bardzo był gotów wierzyć we wpływy Żydów w Polsce i za granicą.

W latach siedemdziesiątych Kobyłko udokumentował swoją wojenną historię także w listach do Żydowskiego Instytutu Historycznego w Warszawie, które następnie Yad Vashem wykorzystało w sprawie przyznania mu w $1993 \mathrm{r}$. medalu Sprawiedliwego wśród Narodów Świata. Prośbę o pośmiertne rozpatrzenie jego kandydatury złożyła Ita Keller ${ }^{15}$. W listach i sprawozdaniach Tadeusz podkreślał swój pozytywny stosunek do Żydów w ogóle oraz heroiczne wysiłki w ratowaniu Fajgi i Ity, nie wspominając o szczegółach porozumienia między nim a żoną. Jego relacja była zgodna z konwencją, podobnie jak wielu innych ubiegających się o tytuł Sprawiedliwego. W dokumentach tego rodzaju nie było miejsca na opis takich aspektów związku, które mogłyby zdyskwalifi-

${ }^{13}$ Por. wszystkie imiona, którymi posługiwała się Fajga, w: Benhaiem Keller, $U$-welibi homa..., s. 252.

${ }^{14}$ Wiosną 1949 r. Żydowska Kongregacja Wyznaniowa w Bytomiu wydała zaświadczenie potwierdzające, że pomógł on w czasie okupacji „osobom narodowości żydowskiej, wychowując je w swoim środowisku" (USHMM, Itta Keller Ben-Haiem Collection, 2007.129.1, Zaświadczenie Żydowskiej Kongregacji Wyznaniowej, Bytom, 3 III 1949 r.).

${ }^{15}$ Ita Keller opisała podróż do Polski i poszukiwanie śladów po Tadeuszu, zob. Benhaiem Keller, U’welibi homa..., s. 105 i 130-133. Kobyłko figuruje na liście Sprawiedliwych wśród Narodów Świata z Polski, Righteous among the Nations Honored by Yad Vashem by 1 January 2019, https://www.yadvashem.org/yv/pdf-drupal/poland.pdf (dostęp 2 XII 2020 r.). Zob. AYV, M.31.2/5604, Righteous among the Nations. 
kować kandydata, jak choćby sugestia, że związek mógł mieć charakter barteru seksualnego czy też służył ratowaniu żydowskich krewnych lub uzyskaniu zapłaty w zamian za pomoc ${ }^{16}$.

\section{Na aryjskich papierach we Lwowie}

Fajga Ginsburg wychowała się w tradycyjnej rodzinie żydowskiej i prawdopodobnie uczęszczała do religijnej szkoły dla dziewcząt Beis Jaakow. Przed wojną należała do młodzieżowej organizacji syjonistycznej, planowała wyjazd do Palestyny, zaręczyła się ${ }^{17}$. W jej karcie rejestracyjnej wydanej przez komitet żydowski w Bytomiu zanotowano jedynie, że urodziła się 31 grudnia 1913 r. w Rymanowie jako córka Rywki i Salomona i że przeżyła we Lwowie na aryjskich papierach $^{18}$. Tadeusz urodził się we Lwowie 15 lipca 1913 r. jako syn Józefa i Stefanii z domu Boczyluk ${ }^{19}$. Pod okupacją sowiecką pracował w dawnej żydowskiej fabryce czekolady, cukru i marmolady Hazet, w której mimo nacjonalizacji nadal zatrudniano wielu Żydów. Latem 1941 r., kiedy Lwów znalazł się w niemieckich rękach, Tadeusz pomagał żydowskim pracownikom z fabryki, zwłaszcza młodym kobietom. Zdobywał dla nich żywność i ukrywał w swoim mieszkaniu, kiedy pojawiły się obawy o wybuch przemocy antyżydowskiej ${ }^{20}$. Jego znajomy

${ }^{16}$ Zob. Gusarov, Sexual Barter and Jewish Women's Efforts to Save Their Lives...; Jan Grabowski, Rescue for Money. Paid Helpers in Poland, 1939-1945, Jerusalem: Yad Vashem, 2008; zob. też idem, Ratowanie Żydów za pieniq̨dze: przemysł pomocy, „Zagłada Żydów. Studia i Materiały" 2008, nr 4, s. 81-108.

${ }^{17}$ Benhaiem Keller, $U$-welibi homa..., s. 253-254. Keller opisała swego dziadka ze strony matki Szlomo Zalmana Ginsburga jako chasyda z Sadagóry (ibidem, s. 227). Pamiętała też, że Fajga mówiła „po niemiecku doskonale” (ibidem, s. 255). Na temat ortodoksyjnych szkół dla dziewcząt zob. Naomi Seidman, Sarah Schenirer and the Bais Yaakov Movement. A Revolution in the Name of Tradition, Liverpool: The Littman Library of Jewish Civilization, współpraca Liverpool University Press, 2019.

${ }^{18}$ AŻIH, Centralna Kartoteka Żydów w Polsce 1945-1951, 303/V/425, 1755/79930. Fajga zarejestrowała się 9 VII 1946 r., jako Hanka (sic!) Fajga Ginsberg, która ukończyła siedem klas. Informacja na temat ojca Ginsburg zob. The Central Database of Shoah Victims' Names, https://yvng.yadvashem.org/index.html?language=en\&s_lastName=Ginzburg\&s_firstName=Salomon\&s_place=Rymanow\&s_dateOfBirth=\&cluster=true (dostęp 2 XII 2020 r.). Na temat roli powojennych komitetów żydowskich zob. David Engel, The Reconstruction of Jewish Communal Institutions in Postwar Poland. The Origins of the Central Committee of Polish Jews, 1944-1945, „East European Politics and Societies” 1996, t. 10, nr 1, s. 85-107.

${ }^{19}$ Zob. USHMM, Itta Keller Ben-Haiem Collection, 2007.129.1, Opis ciągłości wydarzeń. Niestety, dostępne dokumenty - zwłaszcza jego własne zeznania - nie pozwalają na odtworzenie jego dzieciństwa i młodości. Kobyłko opisywał swój status społeczny jako były podoficer zawodowy Wojska Polskiego bez nieruchomości, z zawodu pracownik umysłowy bez stałego zatrudnienia, mieszkający obecnie przy ul. Wolności $59 \mathrm{~m} .16 \mathrm{w}$ Bytomiu.

${ }^{20}$ AYV, M.31.2/5604, „Kto uratował jedno życie ludzkie - uratował cały świat”, k. 1. Ten sam dokument dołączony do listu napisanego w Bytomiu 10 II 1973 r., adresowanego do ŻIH: AŻIH, 301/6612. 
- ks. Banach z kościoła św. Elżbiety - wydał dla nich dokumenty potwierdzające ich „aryjskie” korzenie. Kobyłko towarzyszył również Żydom próbującym dotrzeć ze Lwowa do Starego Samboru (dziś Staryj Sambir, Ukraina) i Rymanowa. W tych właśnie okolicznościach poznał zamożną rodzinę Kellerów ${ }^{21}$. Podróżował między Lwowem a Starym Samborem, przewożąc żywność i przekazując informacje ${ }^{22}$. Zapewne w czasie jednej z takich podróży w marcu 1942 r. poznał Fajgę Ginsburg ${ }^{23}$.W jednym z powojennych listów Kobyłko opisał, jak zaczął się ich związek. Stwierdził, że zamieszkali razem wkrótce po tym, jak pomógł jej uciec „w drodze do obozu” 24 . W późniejszej relacji przedstawił jednak tę historię nieco inaczej: „By uratować choćby jedno życie ludzkie, wyperswadowałem ww. żydówce szukania ratunku w samobójstwie, proponując jej powrót do Lwowa, gdzie miała zamieszkać jako aryjka wraz ze mną jako rzekoma moja żona, ukrywając się pod nazwiskiem Marji Kobyłko"25.

Tadeusz otrzymał akt małżeństwa od ks. Banacha, dzięki czemu Fajga mogła grać rolę jego żony ${ }^{26}$. Fajga i Tadeusz nie czuli się bezpieczni: Fajga nie zarejestrowała się, by nie ryzykować ujawnienia jej prawdziwej tożsamości, i znalazła się na utrzymaniu Tadeusza ${ }^{27}$. Kiedy zaszła w ciążę, urodziła dziecko w jego mieszkaniu i z jego pomocą ${ }^{28}$. Kobyłko opisał to wydarzenie następująco:

W grudniu 1943 roku w wyniku wspólnego pożycia w ramach faktycznego związku małż[eńskiego] urodziło się dziecko płci męskiej, które za zgodą obydwojga rodziców zostało ochrzczone w kościele rzym[sko]kat[olickim], gdzie w urzędzie parafialnym zanotowano legalność dziecka na podstawie fikcyjnego potwierdzenia dokonanego ślubu z osobą pod personaliami, [pod] jakimi egzystowała dana osoba żydowska, co potwierdza metryka urodzenia dziecka, w aktach sprawy załączona ${ }^{29}$.

\footnotetext{
${ }^{21}$ Ibidem, k. 2.

${ }^{22}$ Ibidem, k. 3.
}

${ }^{23}$ Zob. AYV, M.31.2/5604, dwie relacje Kobyłki; AŻıH, 301/6612, k. 3-4. Zob. również Benhaiem Keller, $U$-welibi homa..., s. 18.

${ }^{24}$ USHMM, Itta Keller Ben-Haiem Collection, 2007.129.1, List Tadeusza Kobyłki do Poselstwa Izraela w Polsce, Bytom, 28 XI $1958 \mathrm{r}$.

${ }^{25}$ AYV, M.31.2/5604, „,Kto uratował jedno życie ludzkie - uratował cały świat”, k. 4.

${ }^{26}$ Według aktu małżeństwa zawarli ślub w Gdyni w 1936 r. Zob. AYV, M.31.2/5604, „Kto uratował jedno życie ludzkie - uratował cały świat”, k. 8. W 1950 r. Kobyłko twierdził, że nigdy nie był żonaty, zob. AŻ̇H, 301/6612, Odpis oświadczenia, Bytom, 16 V 1950 r.

${ }^{27}$ AYV, M.31.2/5604, „Kto uratował jedno życie ludzkie - uratował cały świat”, k. 7.

${ }^{28}$ Ibidem, List Tadeusza Kobyłki do Żydowskiego Instytutu Historycznego w Warszawie, Bytom, 10 X 1972 r. Zob. AŻIH, 301/6612, nr 755987, Odpis aktu urodzenia Adama Kobyłki wydanego we Lwowie, urodzonego 11 XII $1943 \mathrm{r}$.

${ }^{29}$ USHMM, Itta Keller Ben-Haiem Collection, 2007.129.1, Opis ciągłości wydarzeń. Zob. również ibidem, List Tadeusza Kobyłki do Poselstwa Izraela w Warszawie, 21 XII 1948 r. W cytowanych listach została zachowana oryginalna pisownia, poprawiono jedynie interpunkcję. 
Wydaje się, że syn Fajgi urodził się około dziewięciu miesięcy po ich wspólnym wyjeździe ze Starego Sambora. Jest więc prawdopodobne, że Adam był biologicznym synem Kobyłki. To, że Fajga była żoną Kobyłki, nie stanowiło już tylko alibi, które pozwalało jej ukrywać się we Lwowie ${ }^{30}$.

Kilka miesięcy po przyjeździe Fajgi do Lwowa Tadeusz wyruszył do Starego Sambora, by ratować jej trzyletnią siostrzenicę, którą - jak napisał w jednej z powojennych relacji - „[wprowadziłem] dodatkowo w poczet mojej rodziny”31. Wyjaśnił również, że ratując dziecko, kierował się „jedynie uczuciem humanitarnym, a z uwagi na to, że było ono spokrewnionem z podopieczną mi już niewiastą żydowską, znalazło w łonie rodziny mojej pełne schronienie, opiekę i utrzymanie, kryjąc się pod nazwiskiem Kobyłko Irena, w charakterze córki" ${ }^{32}$. Podczas wyłapywania pozostałych w Starym Samborze Żydów, którzy zostali następnie deportowani do pobliskiego Sambora, siostra Fajgi Sara (Salka) Keller ukryła swoją trzyletnią córkę Itę w piwnicy. Znalazłszy tam dziecko, Tadeusz uciekł z miasta pieszo, niosąc ją na rękach. Kiedy zauważył, że dziewczynka mówi „żydowskim żargonem", czyli w jidysz, postanowił podać jej dla bezpieczeństwa środki nasenne, a następnie zawiózł do Lwowa. Kobyłko podsumował: „I takim sposobem stałem się przybranym ojcem dziecka, które przyjęło nazwisko Irena Kobyłko"33.

Tadeusz pomagał również innym Żydom - dostarczał im żywność, odzież, fałszywe dokumenty, a także towarzyszył im w drodze do bezpiecznego schronienia. Uciekający z getta Żydzi wiedzieli, że mieszka z Żydówką i że mogą liczyć na jego wsparcie i życzliwość: „Mieszkanie z uwagi na pochodzenie mojej żony znane było jako najbezpieczniejszy punkt w każdym pierwszym etapie jakiejkolwiek ucieczki, gdzie opracowywało się plany działania i pomocy poszczególnym grupom i jednostkom żydowskim"34.

Fajga i Tadeusz zmagali się nie tylko z biedą, lecz także z poczuciem zagrożenia, które nie opuszczało ich nawet na chwilę. Bali się, że znajomi Tadeusza albo sąsiedzi domyślą się, iż Fajga jest Żydówką, i wydadzą ich w ręce władz okupacyjnych. Kiedy Niemcy przeszukiwali ul. Kulparkowską, przy której mieszkali, Fajga „odchodząc ze strachu od zmysłów”, ukryła się w szambie. Z obawy przed aresztowaniem i torturami próbowała się otruć ${ }^{35}$. Wielokrotnie musieli

${ }^{30}$ Zgodnie z zapisem Ity Keller w jej wspomnieniach Fajga zwierzyła się jej w 1976 r., że Adam jest synem Tadeusza i że próbowała przerwać ciążę, ale bezskutecznie (Benhaiem Keller, $U$-welibi homa..., s. 108).

${ }^{31}$ USHMM, Itta Keller Ben-Haiem Collection, 2007.129.1, Opis ciągłości wydarzeń. O ojcu Ity zob. The Central Database of Shoah Victims' Names, Shlomo Keller, https://yvng.yadvashem.org/nameDetails.html?language=en\&itemId=3936984\&ind=7 (dostęp 2 XII 2020 r.).

${ }^{32}$ USHMM, Itta Keller Ben-Haiem Collection, 2007.129.1, Opis ciągłości wydarzeń.

${ }^{33}$ AYV, M.31.2/5604, „Kto uratował jedno życie ludzkie - uratował cały świat”, k. 7.

${ }^{34}$ USHMM, Itta Keller Ben-Haiem Collection, 2007.129.1, List Tadeusza Kobyłki do Poselstwa Izraela w Polsce, Bytom, 28 XI $1958 \mathrm{r}$.

${ }^{35}$ AYV, M.31.2/5604, „Kto uratował jedno życie ludzkie - uratował cały świat”, k. 8. 
zmieniać miejsce pobytu, kiedy tylko sąsiedzi zaczynali podejrzewać, kim jest Fajga. Przez to Tadeusz stracił cały swój majątek ${ }^{36}$. W kwietniu 1944 r. Fajga została rozpoznana na ulicy przez koleżankę, której nieopatrznie podała adres zamieszkania ${ }^{37}$. Pod nieobecność Tadeusza ich mieszkanie zostało przeszukane, a Fajgę wraz z dziećmi aresztowano „pod zarzutem pochodzenia semickiego”. W jednej z relacji Tadeusz zaznaczył, że sam uniknął takiego losu, po czym zdołał doprowadzić do uwolnienia swojej rodziny i ucieczki. Do mieszkania nie mogli już jednak wrócić. „Do chwili opuszczenia terytorium przez okupanta chroniłem się wraz [z moimi] podopiecznymi na peryferiach miasta, wiodąc życie wegetacyjne" ${ }^{\prime 3}$.

\section{Po wyzwoleniu}

Po wyzwoleniu Lwowa Fajga i Tadeusz nadal mieszkali razem, a w październiku 1944 r. zarejestrowali się jako małżeństwo. Posłużyli się przy tym fałszywymi dokumentami okupacyjnymi i odnotowali zarazem, że ich związek trwa już od 1941 r. We wrześniu 1945 r. Kobyłkowie przybyli do Bytomia w ramach tzw. repatriacji obywateli polskich z terenów, które znalazły się po wojnie w granicach Związku Radzieckiego ${ }^{39}$. W swoim zeznaniu Tadeusz wyjaśnił, dlaczego zdecydowali się przemilczeć prawdziwą tożsamość Fajgi we Lwowie, a potem również w Bytomiu:

Nie mogłem rozgłaszać nikomu z rodziny i krewnych, że jestem połączony z osobami żydowskimi, gdyż wówczas antysemityzm w naszym kraju był zbyt silny. Dowód: ekscesy kieleckie w 1946 roku. Moja Pani postanowiła pozostać pod moim nazwiskiem na zawsze jako legalna moja żona. Mieliśmy dzieci wychować w duchu polskim. Nie mieli oni nigdy dowiedzieć się o swoim żydowskim pochodzeniu ${ }^{40}$.

Po przyjeździe do Bytomia Tadeusz podjął pracę w kopalni, a Fajga opiekowała się dziećmi. Jednak obydwoje byli - jak wspominał Tadeusz - „całkowicie

${ }^{36}$ USHMM, Itta Keller Ben-Haiem Collection, 2007.129.1, Opis ciągłości wydarzeń. Zamieszkali wówczas przy ul. Solniczej 35. Zob, AYV, M.31.2/5604, „Kto uratował jedno życie ludzkie - uratował cały świat", k. 7-9; USHMM, Itta Keller Ben-Haiem Collection, 2007.129.1, List Tadeusza Kobyłki do Poselstwa Izraela w Polsce, Bytom, 28 XI 1958 r.

${ }^{37}$ AYV, M.31.2/5604, „Kto uratował jedno życie ludzkie - uratował cały świat”, k. 10.

${ }^{38}$ USHMM, Itta Keller Ben-Haiem Collection, 2007.129.1, Opis ciągłości wydarzeń.

${ }^{39} \mathrm{O}$ żydowskiej społeczności na Ziemiach Odzyskanych zob. Kamil Kijek, Aliens in the Lands of the Piasts. The Polonization of Lower Silesia and Its Jewish Community in the Years 1945-1950 [w:] Jews and Germans in Eastern Europe. Shared and Comparative Histories, red. Tobias Grill, Berlin: De Gruyter, 2018, s. 234-255; Katharina Friedla, „A Naye Yidishe Heym in Nidershlezye." Polnische Shoah-Überlebende in Wrocław (1945-1949). Eine Fallstudie, „S:I.M.O.N. Shoah: Intervention. Methods. Documentation” 2014, t. 1, nr 1, s. 32-42.

${ }^{40}$ AYV, M.31.2/5604, „Kto uratował jedno życie ludzkie - uratował cały świat”, k. 13. 
po przejściach wojennych wyczerpani"41. Postanowili zwrócić się o pomoc do organizacji żydowskich, Kobyłko zgodził się więc, by żona i adoptowana córka zapisały się w miejscowym komitecie żydowskim, natomiast jego syn Adam nie został tam zarejestrowany ${ }^{42}$. Tadeusz odnotował w swojej relacji, że dla Fajgi, trawionej nostalgią, „zew krwi był silniejszy”43. Gdy świecki komitet żydowski zaangażował się bezpośrednio w życie Kobyłków, zwróciło to uwagę rabinów, którzy szukali informacji o losie Fajgi. Co więcej, Tadeusz napisał do Rady Rabinackiej w Tel Awiwie, aby powiadomić o ocaleniu Fajgi jej siostrę Rachelę, która wyemigrowała tam w 1936 r. i poślubiła rabina Cwiego Jehudę Edelsteina. W ten sposób adres Kobyłków trafił również do ortodoksyjnej partii Agudat Izrael ${ }^{44}$. W maju 1946 r. rodzinę Kobyłków odwiedził rabin Jehuda Elinson - członek delegacji rabinów, którzy przybyli z Palestyny do Europy z misją wsparcia wysiłków zmierzających do odnalezienia ocalałych dzieci żydowskich ${ }^{45}$. Dowiedziawszy się o małżeństwie Fajgi z nie-Żydem, z którym miała dziecko, Elinson wyrazić miał oburzenie. Poinformował również rodzinę Fajgi w Palestynie o niepokojącej sytuacji ${ }^{46}$.

Ponieważ tożsamość Ity została odnotowana w komitecie żydowskim, Kobyłków zaczęto namawiać na umieszczenie dziewczynki w żydowskim domu dziecka. Tadeusz odmówił, ponieważ - jak wspominał później - był do dziecka przywiązany. Oponował też przeciwko „uświadomieniu dziecka o jego sierocej doli i jakości pochodzenia, co mogło mu wyrządzić niepowetowaną krzywdę, a mnie narazić na przykre upokorzenia" ${ }^{47}$. Kobyłków odwiedził również niejaki „Kapitan Poker”, prawdopodobnie Aharon Beker, który przedstawił się jako reprezentant żydowskiej „organizacji charytatywnej” i powiadomił Fajgę, że jej krewni w Palestynie pragną jej przyjazdu. Poker (Beker) również chciał umieścić Itę Keller w żydowskim domu dziecka w Zabrzu i zaproponował Tadeuszowi 30 tys. zł jako zwrot kosztów poniesionych w czasie wojny ${ }^{48}$. Wydaje

${ }^{41}$ Ibidem.

${ }^{42}$ USHMM, Itta Keller Ben-Haiem Collection, 2007.129.1, Opis ciągłości wydarzeń.

${ }^{43}$ AYV, M.31.2/5604, „Kto uratował jedno życie ludzkie - uratował cały świat”, k. 13.

${ }^{44}$ Ibidem.

${ }^{45} \mathrm{Na}$ temat misji rabina Icchaka Herzoga, naczelnego rabina aszkenazyjskego w Palestynie, który przybył do Europy, by szukać ocalałych z Zagłady dzieci żydowskich, zob. Nachmany-Gafny, Dividing Hearts..., s. 108-110, 173-174, 265.

${ }^{46}$ Rabin Elinson był blisko związany ze szwagrem Fajgi, rabinem Cwim Jehudą Edelsteinem (1892-1950) z Ramat Haszaron. Por. Wywiad z rabinem Jaakowem Edelsteinem przeprowadzony przez Cwiego Jaakowwsona, 23 III 2017, http://beinenu.com/sites/default/ files/alonim/176_22_23_77.pdf, s. 4-5 (dostęp 2 II 2021 r.).

${ }^{47}$ USHMM, Itta Keller Ben-Haiem Collection, 2007.129.1, Opis ciągłości wydarzeń.

${ }^{48}$ Ibidem. Aharon Beker, działacz syjonistycznej partii religijnej Mizrachi. Służył jako rabin Wojska Polskiego, pomagając rabinowi Dawidowi Kahane - naczelnemu rabinowi WP, stojącemu również na czele Związku Żydowskich Kongregacji Wyznaniowych. Zajmował się poszukiwaniem dzieci żydowskich, które po wyzwoleniu pozostały w rodzinach chrześcijań- 
się, że latem 1946 r. Kobyłko zmienił zdanie. Według sporządzonego wówczas protokołu oddał Itę Żydowskiej Kongregacji Wyznaniowej „pod dalszą opiekę i wychowanie" ze względu na brak środków na jej utrzymanie ${ }^{49}$.

Tadeusz wierzył, że w tym czasie „niektóre żydowskie organizacje przygotowywały grunt pod naszą wspólną emigrację z kraju"50. Jednak 18 sierpnia 1946 r. tylko Fajga z dziećmi opuściła Bytom, zapewniając przy tym męża, że połączą się znowu w Palestynie ${ }^{51}$. Nie jest jasne, czy Tadeusz zdecydował się pozostać w kraju, czy też nie dostał pozwolenia na wspólny wyjazd z Polski ${ }^{52}$. Niemniej wierzył, że ich rozstanie jest tylko czasowe, a emigracja jego najbliższych wraz z innymi Żydami stanowi konieczność w związku z pogromem kieleckim i „mimo pozorów nie kryje w sobie żadnych elementów mogących godzić tak w moje osobiste, jak i stadła rodzinnego dobra" ${ }^{53}$. Pisał potem do Agencji Żydowskiej z prośbą o zaświadczenie, które pozwoliłoby mu dołączyć do żony ${ }^{54}$, w Ambasadzie Państwa Izrael prosił natomiast o wydanie mu wizy ${ }^{55}$. Wszystkie te wysiłki okazały się jednak płonne, Fajga zaś ostatecznie odrzuciła ideę wspólnego życia za granicą, szczególnie w Palestynie. Ostatnią wiadomość od żony otrzymał za pośrednictwem Agencji Żydowskiej dla Palestyny w grudniu

skich i nieżydowskich instytucjach opiekuńczych. Na temat Bekera zob. Nachmany-Gafny, Dividing Hearts..., s. 108 i 115.

${ }^{49} \mathrm{AZZIH}, 301 / 6612$, Odpis protokołu sporządzonego 16 VII 1946 r. w Żydowskiej Kongregacji Wyznaniowej w Bytomiu w obecności Mosesa Neumana i dwóch świadków: Mosesa Gelbarta i Ps[a]chie Löwenberga. W swojej relacji Kobyłko napisał, że został wezwany do Kongregacji, tam zaś, „podkreślając moje położone na polu niesienia pomocy żydom zasługi, rabin Neuman roztoczył przede mną perspektywę lepszej egzystencji w Palestynie, gdzie w pierwszym etapie miała przedostać się wraz z dziećmi żona moja, by po przygotowaniu gruntu do mojej egzystencji zawezwać mnię do siebie" (USHMM, Itta Keller Ben-Haiem Collection, 2007.129.1, Opis ciągłości wydarzeń).

${ }^{50}$ Ibidem, List Tadeusza Kobyłki do Poselstwa Izraela w Polsce, 28 XI 1958 r.

${ }^{51}$ Ibidem, Tadeusz Kobyłko do Poselstwa Izraela w Warszawie, 21 XII 1948 r. Według Ity Keller wyjechali do Pragi pociągiem wraz z innymi dziećmi, które przygotowano do podróży w ramach misji rabina Herzoga (Benhaiem Keller, $U$-welibi homa..., s. 31-32).

${ }^{52}$ W 1958 r. widział w swoim pozostaniu w Polsce spisek o szerokim zasięgu: „Ja nie mogłem wspólnie emigrować, gdyż władze bezpieczeństwa tendencyjnie zabroniły, a choć w tym czasie całe zastępy żydów uchodziły z kraju bez załatwiania jakichkolwiek formalności paszportowych czy repatriacyjnych" (USHMM, Itta Keller Ben-Haiem Collection, 2007.129.1, List Tadeusza Kobyłki do Polskiego Radia „Fala 56”, Warszawa, 15 X 1958 r.).

${ }^{53}$ Ibidem, Opis ciągłości wydarzeń.

${ }^{54}$ AŻIH, 301/6612, 37, Pismo Wydziału Emigracyjnego Agencji Żydowskiej, Biuro, L.dz. 2557/47, podpisane przez Bernarda Johannesa i Mieczysława Wientrauba do Tadeusza Kobyłki, Warszawa, 12 VI 1947 r. List wysłany w odpowiedzi na pismo Kobyłki z 9 VI 1947 r.

${ }^{55}$ Zob. ibidem, 36, Pismo Konsulatu Israela (Azriel Uchmani) w Warszawie do Tadeusza Kobyłki, 17 I 1949 r. Azriel Uchmani obiecał mu tam wizę turystyczną do Izraela, jeśli dostanie paszport. 
1947 r. ${ }^{56}$ Kiedy Fajga wraz z dziećmi zamieszkała w Izraelu, Kobyłko poślubił Marię Słotę i założył w Bytomiu nową rodzinę ${ }^{57}$.

\section{Relacja Tadeusza: ratunek i zdrada}

Listy do żydowskich i nieżydowskich organizacji oraz instytucji w Polsce i za granicą stanowiły dla Tadeusza Kobyłki platformę do przedstawienia jego zasług w udzielaniu Żydom bezinteresownej pomocy w czasie okupacji niemieckiej i doznanej przezeń krzywdy. Choć szczegółowo opisał swoje działania pod okupacją niemiecką, a następnie rozpad związku z Fajgą po wojnie, początek i charakter ich znajomości pozostał w jego korespondencji niejasny. W obszernym oświadczeniu, napisanym najprawdopodobniej pod koniec 1948 lub na początku 1949 r., wspominał ukrywanie Fajgi Ginsburg „w łonie własnej rodziny”, począwszy od marca $1941 \mathrm{r}^{58} \mathrm{~W}$ relacji z 1972 r. swoje małżeństwo nazwał „fikcyjnym”, a Fajgę po prostu „żyjącą u mnie osobą żydowską” lub „podopieczną" ${ }^{59}$. Te zawoalowane sformułowania mogły oczywiście wynikać z faktu, że para nie zawarła formalnego związku małżeńskiego, a kiedy Tadeusz się ożenił (ponownie), nie chciał sprawić nowej rodzinie przykrości. Kobyłko nie wyrażał się precyzyjnie również na temat relacji łączącej Fajgę z Adamem, wyjaśniając, że „jego dziecko”, które urodziło się „na skutek rzeczywistego pożycia małżeńskiego [...], dla zachowania pozorów zostało ochrzczone za zgodą jego matki, a idąc po linji ojca polaka, miało optować na rzecz obywatelstwa polskiego"60. Gdzie indziej stwierdził, że Adam urodził się w jego domu „podczas wojny, bowiem denatka była brzemienna, gdy los chciał, że znalazła schronienie przez okres wojny przy moim boku"61. W liście do Agudat Israel w Londynie Kobyłko skarżył się, że kie-

${ }^{56}$ Ibidem, 38, Agencja Żydowska dla Palestyny do Tadeusza Kobyłki, Jerozolima, 18 II 1948 r. Zob. również USHMM, Itta Keller Ben-Haiem Collection, 2007.129.1, List Tadeusza Kobyłki do Poselstwa Izraela w Polsce, Bytom, 28 XI 1958 r.

${ }^{57}$ W 1950 r., kiedy Kobyłko miał zawrzeć związek małżeński z Marią Słotą, oznajmił, że nigdy wcześniej nie był żonaty i że jest kawalerem. Przyznał natomiast, że „zameldowana u mnie jako żona niejaka Maria Kobyłko z domu Borowicz, córka Juliana i Pauliny z domu Ząbkiewicz - jest osobą fikcyjną, bowiem pod tym nazwiskiem zmuszony byłem chronić ukrywającą się ze mną zamieszkałą wspólnie w moim domu niewiastę żydowską o nazwisku Ginzberg Fani, córkę Salomona i Ryfki Sojchert, urodzoną dnia 31 grudnia 1912 roku w Rymanowie, która od 19 sierpnia 1946 roku opuściła granice Polski i znajduje się w Izraelu". Przyznał również, że Fajga „urodziła u mnie syna, uznany [z] łoża legalnego naszego fikcyjnego małżeństwa, któremu nadano imię Adam, przebywającego przy matce" (AŻIH, 301/6612, 35, Oświadczenie, Bytom, 16 V 1950 r.).

${ }^{58}$ USHMM, Itta Keller Ben-Haiem Collection, 2007.129.1, Opis ciągłości wydarzeń.

${ }^{59}$ AYV, M.31.2/5604, „Kto uratował jedno życie ludzkie - uratował cały świat”, k. 5-7.

${ }^{60}$ USHMM, Itta Keller Ben-Haiem Collection, 2007.129.1, List Tadeusza Kobyłki do Generalnego Konsulatu RP w Jerozolimie, Bytom, 15 IX 1949 r.

${ }^{61}$ AYV, M.31.2/5604, Pismo Tadeusza Kobyłki do Żydowskiego Instytutu Historycznego w Warszawie, Bytom, 10 X 1972 r. 


\section{Studia}

dy Fajga wyjechała z Polski wraz z Itą, „[r]azem z wyżej wymienionymi również opuścił granice kraju mój dwuletni syn Adam, urodzony w czasie wojny w grudniu 1943 roku, któremu Pani Ginzberg była przybraną matką"62. W innym liście nie ujawnił wprost, że Adam był w rzeczywistości synem „żydówki śmiertelnie strwożonej pościgiem gestapo"63. Odnotował tylko, że Ita Keller została siostrą jego syna po tym, jak w sierpniu 1942 r. przywiózł ją do domu, a później Fajga wyjechała z Polski, zabierając - jak podał - „mojego dwuletniego syna Adama”64. To właśnie utrata syna bolała go najbardziej. W dodatku stracił go nie tylko jako ojciec, gdyż jego syn został Żydem.

W swoich świadectwach i korespondencji Tadeusz przedstawiał Fajgę jako kobietę przerażoną, słabą, całkowicie zależną od jego odwagi i inicjatywy, jako bierny obiekt jego wsparcia i pomocy:

W marcu 1942 roku niejaka Żydówka o nazwisku Ginzberg Fajgałe, nie wytrzymując już nerwowo, postanowiła popełnić samobójstwo, nie widząc wyjścia z sytuacji, gdyż aresztowania Żydów i deportacje w nieznanym kierunku były coraz częstrze [sic!]. [...] By uratować choćby jedno życie ludzkie, wyperswadowałem ww. Żydówce szukania ratunku w samobójstwie, proponując jej powrót do Lwowa, gdzie miała zamieszkać jako aryjka wraz ze mną jako rzekoma moja żona, ukrywając się pod nazwiskiem Marji Kobyłko ${ }^{65}$.

Podkreślił również, że po wyzwoleniu Lwowa „współżyjąca ze mną niewiasta żydowska, ulegając procesowi asymilacji, nie przejawiała żadnej skłonności zdemaskowania się wobec otoczenia i powrotu do społeczności żydowskiej”66.

Kobyłko wiązał decyzję Fajgi o wyjeździe z Polski nie tylko z tym, co określił jako „zew krwi” i „nostalgia”, lecz także trudnymi warunkami, w jakich znalazła się jego rodzina po repatriacji do Bytomia. Dlatego też Kobyłkowie nawiązali kontakt z organizacjami żydowskimi w Polsce i rodziną Fajgi w Palestynie. Według Tadeusza świadome działania tych organizacji i krewnych doprowadziły $z$ kolei do rozpadu jego rodziny ${ }^{67}$. Szczególnie siostra Fajgi Rachela nie rozumiała, dlaczego ich związek trwał mimo zakończenia wojny ${ }^{68}$. W wyniku kontaktu z krewnymi w Palestynie i organizacjami żydowskimi w Polsce i za granicą Kobyłkowie znaleźli się w centrum zainteresowania działaczy żydowskich, takich jak rabin Poker (Beker), który pojawił się w mundurze polskiej armii, rozmawiał z Fajgą w jidysz i próbował ją namówić do ucieczki, obiecując wsparcie moralne

${ }^{62}$ USHMM, Itta Keller Ben-Haiem Collection, 2007.129.1, List Tadeusza Kobyłki to Agudas Israel World Organization w Londynien, 15 X $1958 \mathrm{r}$.

${ }^{63}$ Ibidem, Pismo Tadeusza Kobyłki do Polskiego Radia „Fala 56” w Warszawie, Bytom, 15 X $1958 \mathrm{r}$.

${ }^{64}$ Ibidem.

${ }^{65}$ AYV, M.31.2/5604, „Kto uratował jedno życie ludzkie - uratował cały świat”, k. 3-4.

${ }^{66}$ USHMM, Itta Keller Ben-Haiem Collection, 2007.129.1, Opis ciągłości wydarzeń.

${ }^{67}$ AYV, M.31.2/5604, „Kto uratował jedno życie ludzkie - uratował cały świat”, k. 13.

${ }^{68}$ Ibidem, k. 14. 
i materialne. Kontaktował się z nią również rabin z Katowic Gabel, który gościł dwie ciotki Fajgi, gdy te wróciły ze Związku Radzieckiego. Jeszcze inny rabin sąsiad Kobyłki dr Moses Neuman - prowadził świetlicę dziecięcą, z której korzystali Ita i Adam. Pod wpływem spotkań z przedstawicielami środowiska żydowskiego Kobyłko zgodził się na zawarcie „ślubu rytualnego” z Fajgą i wspólną emigrację z Polski do Palestyny ${ }^{69}$.

W czasie wojny przetrwanie Fajgi i dwojga dzieci zależało od decyzji Tadeusza, ale po wojnie ta relacja się odwróciła, a patriarchalny porządek znalazł się pod znakiem zapytania. Jednak w relacjach Tadeusza Fajga nadal była pozbawiona niezależnego głosu i sprawczości. W jego oczach to miejscowa społeczność żydowska w Bytomiu, międzynarodowe organizacje żydowskie i osoby prywatne, które wywarły wpływ na jego żonę, ponosiły odpowiedzialność za jej decyzję, właściwie porwały ją i dzieci. Sugerował również, że w bytomskiej synagodze grożono mu przemocą, jeśli odmówi powrotu dzieci do gminy żydowskiej $^{70}$. Kobyłko wskazał kilka kluczowych momentów, które miały świadczyć o rzekomym żydowskim spisku przeciwko jego małżeństwu i rodzinie ${ }^{71}$. Należało do nich odrzucenie przez niego propozycji umieszczenia Ity Keller w żydowskim sierocińcu. W odpowiedzi na jego decyzję

żydowskie czynniki społeczne [...] uciekły się do innych, skrytych dróg działania, za pomocą których w[yżej] wymieniona sierota miała wrócić do swojej społeczności. Niebawem przystąpiono poprzez szeregi solidaryzującego się w tej materji społeczeństwa żydowskiego, jak i różnych org[anizacji] żydowskich do wywierania nacisku na żydowską stronę w małż[eństwie], pod presją którego spodziewano się dokonać rozkładu małżeństwa, a poprzez to zabezpieczyć sobie uzurpatorskie prawa do podopiecznych mi osób, członków mojej rodziny ${ }^{72}$.

Twierdził, że to Żydzi przekonali Fajgę do „ucieczki” z dziećmi i obiecali jej pomoc: „Sam fakt, że biedna, bez żadnych środków materialnych pozostająca niewiasta zdecydowała się na tak daleką i uciążliwą podróż z dwojgiem małych dzieci, świadczy, że emigrację rodziny mojej finansowały i moralnie popierały jakieś ukryte siły społ[eczeństwa] żydowskiego"73. Kobyłko oskarżył „Żydów” o działania, którym przyświecał jeden cel: „,bezwzględnego rozbicia, skompletowanego na tle działań wojennych tego mieszanego małżeństwa, w konsekwencji tego uzyskanie dla społeczności żydowskiej dwojga z tego małżeństwa pochodzących dzieci, przy zastosowaniu nieetycznej metody jednostronnych faktów

${ }^{69}$ Ibidem, k. 14-15.

${ }^{70}$ Ibidem, k. 15.

${ }^{71}$ USHMM, Itta Keller Ben-Haiem Collection, 2007.129.1, Pismo Tadeusza Kobyłki do Wojewódzkiego Komitetu Żydów w Polsce Katowice, Bytom, 5 I 1949 r.

${ }^{72}$ USHMM, Itta Keller Ben-Haiem Collection, 2007.129.1, Opis ciągłości wydarzeń.

${ }^{73}$ Ibidem, Pismo Tadeusza Kobyłki do Generalnego Konsulatu RP w Jerozolimie, Bytom, 15 IX $1949 \mathrm{r}$. 


\section{Studia}

dokonanych"74. Obraz skoordynowanych działań, które miały na celu zapewnienie, że Ita i Adam zostaną „odzyskani” dla społeczności żydowskiej, nie był pozbawiony kontekstu historycznego ${ }^{75}$. Wielu krewnych i przedstawicieli organizacji żydowskich postrzegało odzyskanie ocalałych dzieci jako swoje podstawowe zadanie, niezbędne nie tylko ze względów religijnych, ale też do odbudowania narodu żydowskiego po Zagładzie ${ }^{76}$.

W styczniu 1949 r. Kobyłko wysłał do Wojewódzkiego Komitetu Żydowskiego w Katowicach pismo, w którym otwarcie oskarżył „pewne elementy żydowskie w solidarnej łączności będące ze sobą" o to, że zmusiły jego żonę do wyjazdu z Polski. Podkreślał przy tym, że działania społeczeństwa żydowskiego dokonywały się według „z góry ukartowanego i przemyślanego planu”, że ukryto przed nim nieetyczne zamiary rozbicia małżeństwa, ale też „bezprzykładnego wywłaszczenia jednostki ludzkiej z nabytych praw opiekuńczych i wychowawczych do całkowitej sieroty żydowskiej z tytułu uratowania jej życia i długoletniego utrzymywania, jakoteż urągający wszelkim uczuciom ludzkim sposób pozbawienia ojca możliwości wychowania i opiekowania się rodzonym nieletnim synem, od którego został izolowany barierą sztucznie wytworzoną"77. Oczekiwał wizy do Izraela, by odwiedzić dzieci, a także wsparcia moralnego ze strony żydowskich organizacji społecznych w Polsce oraz - co musiało brzmieć szczególnie groźnie - zbadania sprawy na forum publicznym ${ }^{78}$. Chciał przy tym ustalić, kto jest odpowiedzialny za „sztuczną psychozę, w konsekwencji której nastąpił rozkład małż[eństwa] mieszan[ego]. W czyim interesie leży konieczność dalszego izolowania obydwojga małżonków, którzy żaden z nich do dziś dnia nie wniósł pozwu o postępowanie rozwodowe"79. Należy pamiętać, że Tadeusz stawiał te zarzuty w okresie pogarszających się stosunków polsko-izraelskich, co doprowadziło do rozwiązania wielu organizacji żydowskich na terenie całego kraju. Jego wypowiedzi, przepojone językiem ówczesnej propagandy prasowej, mogły być odebrane jako poważne zagrożenie, gdyż z łatwością można je było wykorzystać przeciwko tym organizacjom ${ }^{80}$. Kilka lat później podkreślał, że obiecywano mu „należytą egzystencję" w Palestynie, gdzie będzie mógł widywać się z synem. Z tego względu Tadeusz czuł się „zdradzony” nie tylko przez Fajgę

\footnotetext{
${ }^{74}$ USHMM, Itta Keller Ben-Haiem Collection, 2007.129.1, Opis ciągłości wydarzeń.

${ }^{75}$ Ibidem, Pismo Tadeusza Kobyłki do Poselstwa Izraela w Warszawie, Bytom, 21 XII $1948 \mathrm{r}$.

${ }^{76}$ Zob. Nachmany-Gafny, Dividing Hearts..., passim.

${ }^{77}$ USHMM, Itta Keller Ben-Haiem Collection, 2007.129.1, Pismo Tadeusza Kobyłki do Wojewódzkiego Komitetu Żydów w Polsce Katowice, Bytom, 5 I 1949 r.

${ }^{78}$ Ibidem.

${ }^{79}$ USHMM, Itta Keller Ben-Haiem Collection, 2007.129.1, Opis ciągłości wydarzeń.

${ }^{80}$ Zob. Bożena Szaynok, Z historiq i Moskwq w tle. Polska a Izrael 1944-1968, Warszawa: IPN, 2007.
} 
i poszczególne jednostki, lecz także przez całe społeczeństwo żydowskie ${ }^{81}$. Martwił się z powodu pozbawienia go możliwości wychowania biologicznego syna. Szczególnie bolesna zaś była dla Tadeusza świadomość, że Adam został obrzezany; akt ów postrzegał jako gwałt ze strony organizacji żydowskich:

Pod naciskiem osobistego ciężkiego położenia zmuszona była żona moja wraz z dziećmi korzystać z dalszej pomocy org[anizacji] żydowskich, którzy wymusili zgodę żony mojej na obrzezanie syna mego [i] zrobienie go żydem, zanim wylądował w Palestynie. W tym wypadku zupełnie zignorowano i pominięto osobę moją jako pełnoprawnego ojca, opiekuna i wychowawcę dziecka ${ }^{82}$.

Oskarżył społeczność żydowską o wywołanie „antagonizmu rasowego” w związku z jego małżeństwem i zawłaszczenie syna:

Pochodzące z legalnego małżeństwa prawnego dziecko płci męskiej, które wg niepisanej umowy nie było żydem ani nie miało później nim zostać, posiadające pełne nazwisko, imię oraz metrykę urodzenia, zostało jednak jeszcze przed wylądowaniem w Izraelu bez uzyskania pełnej zgody obydwojga rodziców obrzezanem, przyjętem w poczet żyd[owskiej] gminy wyznaniowej, przy równoczesnej falsyfikacji jego personalji, co ma spowodować całkowitą izolację dziecka od naturalnego ojca i całkowite jego wynarodowienie ${ }^{83}$.

W oczach Tadeusza decyzja Fajgi o emigracji była skutkiem przymusu. Obawiając się, że po przyjeździe zostanie pozbawiona jakiejkolwiek pomocy, poddała się i pozwoliła na to, co on sam opisał jako „gwałt dokonany na duszy nieżydowskiego dziecka"84. Przechodząc płynnie od wyznania do obywatelstwa, przypominał, że jego ochrzczone dziecko, „idąc po linji ojca polaka, miało optować na rzecz obywatelstwa polskiego" 85 .

Jeśli początkowo Tadeusz wyobrażał sobie wspólne życie za granicą z Fajgą i Adamem, to obrzezanie nieodwracalnie naznaczyło dziecko jako Żyda. Kobyłko pamiętał o liście żony tłumaczącej tę decyzję presją otoczenia przed wyjazdem do Palestyny, choć sama liczyła na powrót do Polski ${ }^{86}$. Oburzenie Tadeusza wynikało z jego bezradności wobec zaistniałej sytuacji, a mianowicie z presji, jakiej

${ }^{81}$ USHMM, Itta Keller Ben-Haiem Collection, 2007.129.1, Pismo Tadeusza Kobyłki do Polskiego Radia „Fala 56” w Warszawie, Bytom, 15 X 1958 r. Ita Keller zanotowała w swoich wspomnieniach, że Fajga miała zamiar pozostać w związku z Tadeuszem i że obiecano jej, iż Tadeusz dołączy do niej za granicą (Benhaiem Keller, U-welibi homa ..., s. 257).

${ }^{82}$ USHMM, Itta Keller Ben-Haiem Collection, 2007.129.1, Pismo Tadeusza Kobyłki do Poselstwa Izraela w Warszawie, Bytom, 21 XII $1948 \mathrm{r}$.

${ }^{83}$ Ibidem, Pismo Tadeusza Kobyłki do Wojewódzkiego Komitetu Żydowskiego w Katowicach, Bytom, 5 I 1949 r.

${ }^{84}$ Ibidem, Opis ciągłości wydarzeń.

${ }^{85}$ Ibidem, Pismo Tadeusza Kobyłki do Generalnego Konsulatu RP w Jerozolimie, Bytom, 15 IX $1949 \mathrm{r}$.

${ }^{86}$ Ibidem. W piśmie wspominał o liście napisanym w Marsylii 29 VII $1947 \mathrm{r}$. 


\section{Studia}

była poddana jego żona, i jej własnych niejednoznacznych uczuć wobec niego. Brakowało mu języka, który nie odwoływałby się do wizji żydowskiego spisku. W 1948 r. Kobyłko nadal czuł się „prawowitym ojcem” swojego syna i jako taki zażądał z nim spotkania ${ }^{87}$. We wrześniu 1949 r., próbując nawiązać kontakt $\mathrm{z}$ rodziną, zwrócił się do Konsulatu RP w Izraelu o interwencję w jego imieniu i pomoc w odnalezieniu syna, którego, jak zasugerował, „porwano nielegalnie”. Namawiał dyplomatów, aby przesłuchali jego żonę, jej siostrę Rachelę i Itę Keller ${ }^{88}$. Pisał:

Z praw do swego dziecka nigdy nie rezygnowałem ani je nie scedowałem na rzecz jakiejkolwiek drugiej lub trzeciej osoby. Ponieważ istnieją podejrzenia, że syn mój przez zmianę nazwiska został wynarodowiony i przebywa na wychowaniu w jednym z sierocińców żydowskich w Izraelu, nie znając swego pochodzenia, o czym matka jego, o ile nadal żyje, złośliwie go nie informuje, zwracam się w tej sprawie do Wysokiego Konsulatu z usilną prośbą o poruszenie przedmiotowej sprawy u miarodajnych czynników izraelskich, by przez to naprowadzić na ślad ukrywania dziecka i [do] przywrócenia mu należnego nazwiska oraz świadomości jego pochodzenia ${ }^{89}$.

Wyobrażał sobie sprawiedliwe zamknięcie rachunku krzywd - rozwód z żoną i ponowne włączenie Adama do polskiej wspólnoty narodowej:

Wobec tego, że syn mój dochodzi do lat szkolnych, zamierzam poczynić starania o jego powrót do kraju, gdyż zgodnie z polskim ustawodawstwem po 7. roku życia dziecko może przejść pod opiekę ojca. Brak odpowiedniej opieki nad dzieckiem wiąże się tak ze stratą osobist[ą] dziecka, jak i jego ojca, jak i stratą społeczną narodu polskiego. Oddawszy tak wielkie bezinteresowne usługi dla dobra narodu żydowskiego, mam prawo żądać zwrotu mi syna, który został, jak z podanych faktów wynika, jako dwuletnie dziecko uprowadzone z kraju po to, by nie zostało zaprzepaszczone dla przetrzebionego narodu żydowskiego ${ }^{90}$.

Wydaje się, że dziesięć lat później Tadeusz nadal chciał odwiedzić dzieci w Izraelu ${ }^{91}$. Poza skontaktowaniem się z Adamem i Itą zamierzał zapytać swoją pierwszą żonę, dlaczego "tak po świńsku postąpiła” - a wszystko to w ramach przysługujących mu praw obywatela polskiego ${ }^{92}$. Pisząc ponownie do ambasady

${ }^{87}$ USHMM, Itta Keller Ben-Haiem Collection, 2007.129.1, Pismo Tadeusza Kobyłki do Poselstwa Izraela w Warszawie, Bytom, 21 XII $1948 \mathrm{r}$.

${ }^{88}$ Ibidem, Pismo Tadeusza Kobyłki do Generalnego Konsulatu RP w Jerozolimie, Bytom, 15 IX $1949 \mathrm{r}$.

${ }^{89}$ Ibidem. Tadeusz zakończył swój list „z proletarjackim pozdrowieniem”.

${ }^{90}$ Ibidem.

${ }^{91}$ USHMM, Itta Keller Ben-Haiem Collection, 2007.129.1, Pismo Tadeusza Kobyłki do Poselstwa Izraela w Polsce, Bytom, 28 XI $1958 \mathrm{r}$.

${ }^{92}$ Ibidem, Pismo Tadeusza Kobyłki do Polskiego Radia „Fala 56” w Warszawie, Bytom, $15 \times 1958 \mathrm{r}$. 
Izraela w listopadzie 1958 r., Kobyłko skarżył się, że nie ma szans na wyjazd do tego państwa ze względu na trudną sytuację, ale nadal był głęboko zainteresowany losem swojego syna Adama ${ }^{93}$. Pisał w rozpaczy:

12 lat borykam się z trudnościami, szukam różnych kontaktów, lecz bezskutecznie i beznadziejnie. $\mathrm{Z}$ ubolewaniem stwierdziłem, że zostałem sromotnie oszukany przez tych, którym świadczyłem i życzyłem najlepiej, przez tych, za których chciałem dobrowolnie, gdyby tego zaszła potrzeba, umrzeć śmiercią męczeńską ${ }^{94}$.

Zastanawiając się, dlaczego Adam i „uratowana sierota” nie wiedzą o jego poświęceniu w czasie wojny, doszedł do wniosku, że taka niewdzięczność może być jedynie wynikiem przedwczesnej śmierci samej Fajgi. I znów tym, co bolało go szczególnie, a być może czym miał nadzieję wstrząsnąć odbiorcą, były pogłoski, że jego syn „pod innym nazwiskiem żyje w Tel Awiwie Ramath Hasharon wzgl[ędnie] Bnej Kidmach i uczy się w seminarium rabinackim"95.

Dumny ze swojej roli w uratowaniu Ity, Kobyłko nie martwił się pogłoskami, że dziewczynkę „przywrócono społeczności żydowskiej”, bolał jednak nad tym, że w Izraelu znalazła się podobno w domu dziecka. Uważał, że w ten sposób społeczeństwo żydowskie odebrało mu prawa opiekuna dziecka, a ponadto pozostawiło bez należnej mu rekompensaty. Chodziło więc nie tyle o to, że Ita została ponownie Żydówką, ile o to, że Tadeuszowi nie zwrócono poniesionych kosztów jej utrzymania i nie doceniono jego okupacyjnego heroizmu ${ }^{96}$. Choć w urzędowej korespondencji podnosił wielokrotnie sprawę Ity, w odróżnieniu od biologicznego syna Adama nie żądał jej powrotu. Na przykład w liście do Polskiego Radia z 1958 r. pisał z jednej strony o tęsknocie za synem, a z drugiej ubolewał, że Ita nie wie o swoim „cudownym ocaleniu ani o mężczyźnie, któremu zawdzięczała życie" 97 .

Choć Kobyłko obarczał odpowiedzialnością za wyrządzoną mu krzywdę całe społeczeństwo żydowskie, szczególnie obwiniał ortodoksyjnych Żydów. Dlatego zwracał się do Agudat Israel - ich reprezentacji politycznej, w Drugiej Rzeczypospolitej wpływowej partii politycznej. Pisząc do siedziby Światowej Organizacji Agudat Israel w Londynie, miał nadzieję, że uzyska informacje na temat Fajgi i dzieci oraz spotka się z uznaniem za pomaganie Żydom pod okupacją ${ }^{98}$. Oczeki-

${ }^{93}$ Ibidem, Pismo Tadeusza Kobyłki do Poselstwa Izraela w Polsce, Bytom, 28 XI 1958 r.

${ }^{94}$ Ibidem.

${ }^{95}$ Ibidem.

${ }^{96}$ USHMM, Itta Keller Ben-Haiem Collection, 2007.129.1, Pismo Tadeusza Kobyłki do Wojewódzkiego Komitetu Żydowskiego w Katowicach, Bytom, 5 I 1949 r.

${ }^{97}$ Ibidem, Pismo Tadeusza Kobyłki do Polskiego Radia „Fala 56” w Warszawie, Bytom, 15 X $1958 \mathrm{r}$.

${ }^{98}$ Agudat Israel nie pozwolono po wojnie na wznowienie działalności w komunistycznej Polsce (ibidem, Pismo Tadeusza Kobyłki do Agudath Israel World Organization w Londynie, 15 X 1958 r.). 


\section{Studia}

wał wdzięczności nie tylko od Ity, ale ogólnie od społeczności żydowskiej, a być może nawet roztoczenia nad nim opieki. Tymczasem społeczność żydowska go zawiodła: „poczucie doznanej krzywdy powiększa z każdym dniem moją gehennę, które spotyka mię tylko dlatego, iż potrafiłem znaleźć w sobie dużą dozę heroizmu i uczucia ludzkiego w stosunku do nieszczęsnych ofiar". Dodawał, że musi znosić codzienne upokorzenia, ponieważ „w obecnym układzie stosunków społeczno-politycznych w naszym kraju miast spotykać się z uznaniem i sympatią jak nie całego społeczeństwa, to przynajmniej czynnik[ów] reprezentujących sfery żydowskie, wręcz przeciwnie, spotyka mię na każdym kroku szykana oraz niechęć, co przy każdej sposobności jest mi wytykane i brane za złe" ${ }^{\prime 99}$.

Kobyłko oskarżał Żydów nie tylko o „rasizm religijny i narodowy”, lecz także zmuszenie Fajgi „do ślepego posłuszeństwa odnośnie [do] losu jej dzieci”100. Największa krzywda dotyczyła Adama, który „został pozbawiony ojca i ojczyzny"101. Co więcej, Tadeusz podejrzewał, że dane osobowe Adama zostały zmienione: „syn mój przez zmianę nazwiska został wynarodowiony i przebywa na wychowaniu $\mathrm{w}$ jednym z sierocińców żydowskich w Izraelu, nie znając swego pochodzenia”, żądał więc przywrócenia dziecku nazwiska i „świadomości jego pochodzenia"102. W oczach ojca Adam padł ofiarą żydowskiego spisku mającego na celu uczynienie z niego członka innej wspólnoty narodowej. W swoich listach Kobyłko wspominał o odwiedzających jego mieszkanie rabinach, którzy najpierw starali się przekonać Fajgę do opuszczenia męża, a potem do obrzezania Adama, krzywdząc w ten sposób zarówno ojca, jak i samo dziecko. W tych oskarżeniach można usłyszeć echo legendy o porywaniu chrześcijańskich dzieci i mordzie rytualnym. W wypadku Adama rytuał przeprowadzono na ciele ochrzczonego dziecka. Nawiązując do porwania chrześcijańskiego dziecka przez Żydów, przy udziale rabinów, Kobyłko formułował jednak swoje oskarżenia w kategoriach świeckich i narodowych raczej niż religijnych. Zresztą w jednym ze świadectw sugerował, że był gotów na „ślub rytualny” z Fajgą jako warunek ich wspólnego wyjazdu do Palestyny ${ }^{103}$. W niedatowanym świadectwie sporządzonym na początku lat siedemdziesiątych wyraził również swój pozytywny stosunek do zmiany wyznania ${ }^{104}$.

Korespondencja Tadeusza dotyczyła nie tylko jego związku z Fajgą i wyjazdu dzieci, lecz także jego kłopotów wyrażających się brakiem uznania w powojennej Polsce dla tych, którzy w czasie okupacji niemieckiej udzielali Żydom pomocy. Tuż po wyzwoleniu ludzie ci często prosili uratowanych przez siebie Żydów

${ }^{99}$ Ibidem.

${ }^{100}$ USHMM, Itta Keller Ben-Haiem Collection, 2007.129.1, Pismo Tadeusza Kobyłki do Generalnego Konsulatu RP w Jerozolimie, Bytom, 15 IX 1949 r.

101 Ibidem.

${ }^{102}$ USHMM, Itta Keller Ben-Haiem Collection, 2007.129.1, Pismo Tadeusza Kobyłki do Wojewódzkiego Komitetu Żydowskiego w Katowicach, Bytom, 5 I 1949 r.

${ }^{103}$ AYV, M.31.2/5604, „Kto uratował jedno życie ludzkie - uratował cały świat”, k. 14.

${ }^{104}$ Ibidem. 
i organizacje żydowskie o nieujawnianie ich nazwisk w obawie przed odwetem ze strony rodaków. W liście z 1958 r. do ambasady Izraela Kobyłko z rozpaczą opisał szczegółowo, jak zamiast z szacunkiem spotyka się z poniżeniem i nękaniem: „Otoczenie, w którym jestem zmuszony przebywać, nie nazywa mnie inaczej jak paskudnym żydem, rzucają na moją osobę paszkwile, szykanują i podjudzają do tego stopnia, że mimo sprzyjających warunków społeczno-politycznych w naszym kraju czuję się nieswojo, a bezpieczeństwo moje narażone jest na szwank". Oprócz niego szykanom poddawano jego nową żonę, którą poślubił po odejściu Fajgi, a także ich troje małych dzieci w wieku ośmiu, pięciu i czterech lat. Kobyłko skarżył się: „Żona jest o 17 lat młodsza, to wytykają jej, że jest bezwstydna, że żyje ze Żydem itp. Ta po dniach całych płacze i narzeka na swój los, chce mnię z tego powodu opuścić i wyjechać do Niemiec, w którym to kierunku czyni starania, a cóż ja mam począć". Prosił o pomoc w zmianie miejsca pracy i zamieszkania ${ }^{105}$. W liście do Agudat Israel stwierdził z goryczą, że poza ignorującymi jego zasługi „Żydami” również polskie społeczeństwo lekceważy jego bohaterstwo i wręcz ma mu jego dobre uczynki za złe. Mieszkając w powojennej Polsce, został „oskarżony o bycie Żydem”, co go upokorzyło, ponieważ nie był „prawdziwym Żydem” 106 .

Mając nadzieję na zmianę sytuacji, Kobyłko napisał też do popularnej audycji radiowej „Fala 56”, podejmującej interwencje w imieniu słuchaczy ${ }^{107}$. Nie liczył już na odnalezienie syna. Przedstawiał się raczej jako ktoś, kto pomagał Żydom w czasie wojny, działał odważnie, a tym samym zasługiwał na uznanie i wsparcie moralne. Z dnia na dzień cierpiał coraz bardziej, dlatego prosił o wskazanie mu kierunków, „w jakich dalej winienem iść, by podołać wszelkim piętrzącym się przede mną trudnościom”, wyrażał ponadto nadzieję „na interwencję władz”108. Kobyłko wiele miejsca poświęcił przeżyciom w powojennej Polsce, szczególnie po wyjeździe Fajgi:

ironia, drwiny, szykany nawet $\mathrm{w}$ miejscu zamieszkania i pracy są chlebem powszednim. Wołają na mnie, że jestem żydem, plotkują, że żona moja bezwstydnie żyje z żydem na fiarę [sic!], aczkolwiek zawarłem z nią, mimo że jestem ateistą, obok cywilnego i ślub kościelny. Dzieci moje są również z tego powodu spośledzeni. Nikt mnie nie broni, żadna opieka ze strony społ[eczeństwa] żydowskiego, a wręcz przeciwnie, i ci, gdzie mogą, to mi szkodzą ${ }^{109}$.

${ }^{105}$ USHMM, Itta Keller Ben-Haiem Collection, 2007.129.1, Pismo Tadeusza Kobyłki do Poselstwa Izraela w Polsce, Bytom, 28 XI $1958 \mathrm{r}$.

106 Ibidem, Pismo Tadeusza Kobyłki do Agudath Israel World Organization w Londynie, $15 \times 1958 \mathrm{r}$.

107 Ibidem, Pismo Tadeusza Kobyłki do Polskiego Radia „Fala 56” w Warszawie, Bytom, $151958 \mathrm{r}$.

108 Ibidem.

${ }^{109}$ Ibidem. Położenie Kobyłki musiało stać się w tym czasie, po odwilży październikowej 1956 r., szczególne trudne (Paweł Wieczorek, „Sztuczny antysemityzm”. Antyżydowskie wystapienia na Dolnym Śląsku w 1956 roku [w:] Przemoc antyżydowska i konteksty akcji pogromo- 
Kobyłko zwrócił się do radia z prośbą o powiadomienie odpowiednich agencji, aby jego głos wreszcie został wysłuchany. Spodziewał się, że w popularnym programie radiowym udzielą mu rady i pomogą przenieść się do innego miasta w Polsce, gdzie będzie mógł żyć z rodziną spokojnie i skromnie. Uważał, że to położy kres nękaniu, uwalniając ich z tej „okrutnej matni” ${ }^{110}$. Przedstawiał się także jako lojalny obywatel PRL, argumentując, że mógł wszak napisać do Radia Wolna Europa, gdzie „wrogowie ludu” byliby więcej niż chętni do pomocy. Chciał również skontaktować się z zarządem „odznaczenia Żegota”, które miało nagradzać za „okazanie uczucia ludzkości”, gdyż, jak sądził, i on na takie odznaczenie zasłużył ${ }^{111}$.

W listach do „Fali 56" i innych adresatów Kobyłko analizował swoje wysiłki we Lwowie, opisując nawet intymne szczegóły, inne zaś przedstawiając tylko ogólnikowo. Z jego późnego świadectwa, bardziej niż z pozostałych, wyłania się złożona historia udzielania pomocy, a zarazem, być może, przypadek barteru seksualnego $\mathrm{w}$ kontekście niestannego zagrożenia i przywiązania emocjonalnego do wojennej rodziny ${ }^{112}$. W piśmie do Żydowskiego Instytutu Historycznego oświadczył: „ja sam w czasie wojny na terenach Lwów-Sambor-Drohobycz wiele uczyniłem dla ludności żydowskiej, dysponując ogromnym materiałem dowodowym, a w szczególności przez okres całej wojny, począwszy od marca 1942 do 18 sierpnia 1946, żywiłem, wychowywałem i ponosiłem trudy i męczarnie razem z rodziną będąc[ą] w pojęciu ustawy norymberskiej zakwalifikowaną jako żydowska"113. W ten sposób Kobyłko podkreślił szerszy kontekst uratowania Fajgi i ciągłość swojej roli jako opiekuna Żydów w czasie wojny i po wyzwoleniu. Ostatni zachowany list Kobyłki, z marca 1973 r., był skierowany do Yad Vashem w Jerozolimie, instytucji zajmującej się dokumentowaniem i upamiętnianiem Holokaustu. Opisał w nim ponownie swoją rolę w czasie wojny, bolejąc nad tym, że został zapomniany i że „nie zasadzono [mu] symbolicznego drzewka na wzgórzu jerozolimskim"114.

wych na ziemiach polskich $w$ XX wieku, red. Konrad Zieliński, Kamil Kijek, Lublin: Wydawnictwo UMCS, 2016, s. 211-248).

${ }^{110}$ USHMM, Itta Keller Ben-Haiem Collection, 2007.129.1, Pismo Tadeusza Kobyłki do Polskiego Radia „Fala 56” w Warszawie, Bytom, 15 X 1958 r.

${ }^{111}$ Ibidem. Kolejny list do programu wysłał 28 XI 1958 r. Nie jest jasne, jakie odznaczenie miał na myśli, ponieważ Yad Vashem przyznało tytuł Sprawiedliwego po raz pierwszy w $1963 \mathrm{r}$.

${ }^{112}$ Na temat barteru seksualnego zob. Anna Hájková, Sexual Barter in Times of Genocide. Negotiating the Sexual Economy of the Theresienstadt Ghetto, „Signs” 2013, t. 38, nr 3, s. 503-533.

${ }^{113}$ AYV, M.31.2/5604, Pismo Tadeusza Kobyłki do Żydowskiego Instytutu Historycznego w Warszawie, Bytom, 10 X 1972 r.

${ }^{114}$ AŻ̇H, 301/6612, 12, Pismo Tadeusza Kobyłki do Żydowskiego Instytutu Historycznego w Warszawie, Bytom, 10 II 1973 r. 


\section{Relacja Fajgi: racjonalny związek i więź emocjonalna}

Choć Tadeusz uznał listy od Fajgi wysyłane do niego z Europy za część planu, który miał go zniechęcić do ścigania rodziny, jej korespondencja wydaje się raczej wskazywać na poczucie zagubienia emocjonalnego ${ }^{115}$. W swoich listach rozważała nie tylko stojący przed nią wybór przyszłości dla siebie i dzieci, lecz także trudne decyzje osobiste, które podjęła wcześniej. Wzruszające, czułe, ale też pełne żalu, rzucają światło na związek z Tadeuszem, sugerując, że była to relacja pełna dwuznaczności. Świadczą one również o tym, że Fajga nie była początkowo pewna słuszności decyzji o wyjeździe z Polski. Próbowała przekonać do niego Tadeusza i siebie samą, zarazem wspominając ich trudny związek.

Początkowo przypominała Tadeuszowi, że nadal jest odpowiedzialny za utrzymanie rodziny, złościła się na niego: „Więc zamiast się zająć poszukiwaniem jakiejś stałej pracy, by dzieci mogli mieć swój dom i ojca, to Ty myślisz, jak wyciągnąć pieniądze za to, że żona z dziećmi wyjechała"116. Wciąż czuła przywiązanie do męża. W liście wysłanym do Tadeusza z Schirmeck w Alzacji w listopadzie 1946 r. skarżyła się, że rzadko do niej pisze. Chciała poznać szczegóły jego życia i zapewniała o swojej wierności. Zapytała go również kokieteryjnie, czy podoba mu się wysłane przez nią zdjęcie, dając do zrozumienia, że nadal chce być w jego oczach atrakcyjna ${ }^{117}$.

Kilka tygodni później Fajga dzieliła się z mężem szczegółami na temat życia codziennego, wyrwanych zębów i planowanych wizyt u dentysty oraz ceny tych usług ${ }^{118}$. Wysłała mu zdjęcie, na którym była z dziećmi, a opisując je, znów martwiła się, że może już mu się nie podobać: „synek słodki, Ita głowę zadziera do góry, ja też niedobrze wyszłam, boję się, że jak mnie zobaczysz, to Ci się odechce do mnie przyjechać". Chciała wiedzieć więcej o życiu towarzyskim Tadeusza, prosiła go również o przysłanie zdjęcia, jednocześnie odnosząc się do jego problemu z alkoholem „Niech ja zobaczę, jak Ty wyglądasz po częstym zaglądaniu do kieliszka"119. Fajga wielokrotnie zapewniała Tadeusza o swojej niezmiennej lojalności i braku zainteresowania innymi mężczyznami ${ }^{120}$. Powtarzała, że tęskni za mężem i że rozstanie było dla niej bolesne: „Jestem b[ardzo] uczuciowa i jak się do kogoś przywiążę, to sercem i duszą"121. Dopytywała, czy też za nią tęskni ${ }^{122}$.

${ }^{115}$ USHMM, Itta Keller Ben-Haiem Collection, 2007.129.1, Opis ciągłości wydarzeń.

${ }^{116}$ Ibidem, List Fajgi Ginsberg do Tadeusza Kobyłki, Schirmeck, 10 XI 1946 r.

117 Ibidem.

${ }^{118}$ USHMM, Itta Keller Ben-Haiem Collection, 2007.129.1, List Fajgi Ginsberg do Tadeusza Kobyłki, Schirmeck, 15 I 1947 r.

${ }^{119}$ Ibidem, List Fajgi Ginsberg do Tadeusza Kobyłki, Schirmeck, 15 I 1947 r. Fajga podpisała swój list „Twoja Manusia”, przesyłając mu ucałowania od siebie i dzieci.

${ }^{120}$ Ibidem, List Fajgi Ginsberg do Tadeusza Kobyłki, Strasburg, styczeń 1947 r. Zob. również jej list datowany w Schirmeck 15 I 1947 r.

${ }^{121}$ Ibidem, List Fajgi Ginsberg do Tadeusza Kobyłki, Marsylia, 8 VII 1947 r.

122 Ibidem, List Fajgi Ginsberg do Tadeusza Kobyłki, 10 III 1947 r. List kończy się słowami: „Bądź zdrów i baw się dobrze całuję Cię mocno Maria”. 


\section{Studia}

Fajga nie taiła swoich wątpliwości co do wyjazdu z Polski, gdzie miała dach nad głową, znała język i mogła mieć nadzieję na zatrudnienie. Źle znosiła tymczasową egzystencję emigrantki we Francji, tam bowiem miała ograniczone perspektywy ${ }^{123}$. Dlatego jesienią 1946 r. wspomniała o Polakach, którzy zdecydowali się wrócić do kraju, zniechęceni trudnymi warunkami życia za granicą, i rozważała decyzję o powrocie do Polski wiosną $1947 \mathrm{r}^{124}$

Kilka tygodni później, w Schirmeck, Fajga napisała kolejny list przepełniony poczuciem niepewności: „Takbym Tadziu chciała, żeby to życie nam się jakoś ułożyło, byśmy nareszcie po tych przejściach też mogli żyć jak ludzie"125. Zarazem karciła męża, bo choć rozumie, że „musi człowiek czasem dla humoru lub innych powodów czegoś się napić, ale wszystko z umiarem, to wygłupianie się, gdy się jest podchmielonym, jest takie nieetyczne, że aż wstręt bierze, ale myślę, że mój Tadzio wie, że trzeba czasem swój nałóg w karbach trzymać". Radziła, by pozostał w Polsce, ponieważ nikt mu nie pomoże w zorganizowaniu jego emigracji do Francji w celu połączenia się z żoną i dziećmi. Tłumaczyła, że osiedlenie się za granicą wymaga pieniędzy i pomocy, a ona nie ma pewności, czy może liczyć na pomoc brata Bernarda. Jednocześnie miała nadzieję, że Kobyłko będzie łożył na utrzymanie syna. Wreszcie odwołując się do jego roli jako ojca, prosiła, by uważał na siebie: „już nie mówię o żonie, ale synka masz takiego słodkiego, że warto dla niego żyć"126.

W listach Fajgi wysłanych z Francji powraca wątek tymczasowości, lęku i zmęczenia trudnymi warunkami bytowymi. W kwietniu 1947 r. sugerowała, że po wyjeździe z Polski znalazła się w sytuacji bez wyjścia: mieszkała w złych warunkach, nie znalazła też dla siebie miejsca wśród prężnie działających organizacji i partii, których propaganda ją irytowała. Jednocześnie z goryczą odnotowała, że nie ma już dokąd wrócić ${ }^{127}$. Narzekała na towarzystwo innych ocalałych Żydów: „Gdy się patrzę na tych ludzi, pytam się, gdzie się cała inteligencja podziała, sam plebs został, ludzie bez kultury, ale biedni, wymęczeni w obozach niemieckich"128. Obawiała się, że ona i jej towarzysze nie zostaną wpuszczeni do Palestyny i podobnie jak wielu ocalałych trafią jako internowani na Cypr ${ }^{129}$.

${ }^{123}$ Ibidem, List Fajgi Ginsberg do Tadeusza Kobyłki, Schirmeck, 15 I 1947 r., i list datowany w Marsylii 8 VII $1947 \mathrm{r}$.

${ }^{124}$ Ibidem, List Fajgi Ginsberg do Tadeusza Kobyłki, Schirmeck, 15 I 1947 r.

${ }^{125}$ Ibidem, List Fajgi Ginsberg do Tadeusza Kobyłki, Schirmeck, 23 II 1947 r.

${ }^{126}$ Ibidem. Fajga podpisała list, używając swego okupacyjnego imienia i wyrażając emocje, które nie zapowiadały rozpadu związku: „Bądź zdrów / całuję Cię mocno / Twoja stęskniona Maria".

${ }^{127}$ USHMM, Itta Keller Ben-Haiem Collection, 2007.129.1, List Fajgi Ginsberg do Tadeusza Kobyłki, 1 IV 1947 r.

${ }^{128}$ Ibidem, List Fajgi Ginsberg do Tadeusza Kobyłki, Marsylia, 8 VII 1947 r.

${ }^{129} \mathrm{Na}$ temat sytuacji imigracji żydowskiej do Palestyny zob. Arieh J. Kochavi, The Struggle against Jewish Immigration to Palestine, „Middle Eastern Studies” 1998, t. 34, nr 3, s. 146-167. 
Te refleksje sprawiły, że gratulowała mężowi jego decyzji o pozostaniu w Polsce: „nie chciało Ci się iść na tułaczkę, miałeś zupełną rację, bo życia tutaj nawet wegetacją nie można nazwać"130. Już w drodze do Palestyny wypominała Tadeuszowi, że nie podjął zdecydowanych kroków, by namówić ją do powrotu do Polski. Czuła, że gdyby wróciła, „to po tygodniu usłyszałabym, po coś wróciła, a mnie byłoby szalenie przykro, że miałam rację, i wówczas żarłabym ze siebie skórę, wymawiając sobie - po co faktycznie wróciłam"131.

Tłumaczyła mu, dlaczego wyjechała z Polski, podkreślając przede wszystkim strach przed biedą i jej własny brak zaradności ${ }^{132}$. Pisała też o samotności, codziennych trudnościach, o braku prywatności. Była przekonana, że gdyby Tadeusz wyjechał razem z nią i dziećmi, winiłby ją za to wszystko, co by ich tam spotykało, życie emigrantów doprowadziłoby więc do konfliktów: „Ciężko mi samej żyć, nie ma nawet z kim słowa pomówić, ale jestem bardzo zadowolona, że Ciebie tutaj nie ma, byś się ze mną stale kłócił, na jakiego diabła mi to trzeba było, i miałbyś zupełną rację"133.

Martwiła się również, że jej małżeństwo z nie-Żydem nie zostanie potraktowane życzliwie przez organizacje żydowskie, które wspierały jej emigrację: „Zabronić mi nie mogą, by nawet Turek był moim mężem, ale oni w ramach tych nie będą u siebie tego tolerowali" ${ }^{134}$. W innym liście pisała, że Tadeusz mógł być „nawet Hindusem”, a więc jego pochodzenie nie odegrało żadnej roli w rozpadzie ich związku. W istocie małżonkowie nie potrzebowali „ani księdza, ani rabina", by podjąć decyzję o rozstaniu ${ }^{135}$. Fajga podkreślała swoją obojętność wobec religii i żydowskich rytuałów, dzieląc się z Tadeuszem wątpliwościami co do obrzezania Adama. Świadoma rosnącej presji żydowskiego otoczenia po wyjeździe z Polski, odkładała przeprowadzenie tego rytuału ${ }^{136}$. Fajga szukała rady brata w sprawie „operacji dziecka”, czyli najpewniej właśnie obrzezania Adama. Bernard uważał, że „dla zdrowia dziecka toby było wskazanem, ale jak

${ }^{130}$ USHMM, Itta Keller Ben-Haiem Collection, 2007.129.1, List Fajgi Ginsberg do Tadeusza Kobyłki, 10 III 1947 r.; ibidem, List Fajgi Ginsberg do Tadeusza Kobyłki, Marsylia, 8 VII 1947 r. W liście wysłanym już z Tel Awiwu Fajga sugerowała, że Tadeusz powinien być jej wdzięczny za to, że nie wyemigrował (ibidem, List Fajgi Ginsberg do Tadeusza Kobyłki, 1 XII 1947 r.).

${ }^{131}$ Ibidem, List Fajgi Ginesberg do Tadeusza Kobyłki, Marsylia, 8 VII 1947 r.

${ }^{132}$ Fajga pisała: „Ja chciałam wyjechać, bo miałam przed oczami widmo nędzy, jak nie będzie transportu, nie będzie co jeść, przyznaję, że jestem życiowo niezaradna i nie wiedziałam, do czego się wziąść, by zahandlować i zarobić, by pomóc w utrzymaniu domu" (ibidem, List Fajgi Ginsberg do Tadeusza Kobyłki, Schrimeck, 15 I 1947 r.; zob. również ibidem, List Fajgi Ginsberg do Tadeusza Kobyłki, 10 III 1947 r.).

${ }^{133}$ Ibidem, List Fajgi Ginsberg do Tadeusza Kobyłki, 10 III 1947 r. Zob. również jej list ze stycznia 1947 r., w którym wspomina „nadszarpnięte nerwy”, przez co nie zniosłaby „gderania po całodziennej ciężkiej pracy”, gdyby małżonkowie wyemigrowali razem.

${ }^{134}$ Ibidem, List Fajgi Ginsberg do Tadeusza Kobyłki, 10 III 1947 r.

135 Ibidem, List Fajgi Ginsberg do Tadeusza Kobyłki, Tel Awiw, 1 XII 1947 r.

${ }^{136}$ Ibidem, List Fajgi Ginsberg do Tadeusza Kobyłki, 10 III 1947 r. 


\section{Studia}

zamierzam wracać, to nie ma sensu"137. Decyzja o obrzezaniu Adama była więc równoznaczna z porzuceniem myśli o powrocie do Polski, a zarazem oznaczała nieodwracalny już powrót do żydowskiej tożsamości i społeczności ${ }^{138}$.

Wielokrotnie nawiązywała do swojego wieku i wyglądu: „Zupełnie jasno sobie zdaję sprawę, że nie jestem odpowiednią żoną dla Ciebie, bo wyglądam o 10 lat starzej od Ciebie, za parę lat będę wyglądała jak staruszka, a Ty będziesz w pełni sił mężczyzną, a wtedy na co Ci będzie potrzebna stara baba, i w dodatku [...] nawet w Bytomiu Ci już było przykro ze mną wyjść, bo poważnie wyglądam" ${ }^{139}$. Jej wysiłki, by pozostać atrakcyjną, były w jej przekonaniu skazane na porażkę: „Dziś może też wyglądam na tyle lat, ile mam, jest to zresztą słabą stroną każdej kobiety i nigdy się naprawdę nie wie, ile ma lat. Tadziu, ja muszę podtrzymywać może uchodzącą młodość farbowaniem włosów, sztucznemi zębami etc., a Ty jesteś młody i wyglądasz na dziesięć lat młodszy, jak jesteś, i gdy pierwszy gniew Twój przeminie, dodasz [sic!] mi rację"140. Rozmyślając nad wspólną przyszłością, Fajga kreśliła nieuchronny scenariusz losu kobiety wzgardzonej, gdyby pozostała z Tadeuszem lub zdecydowała się na powrót do niego:

Jeszcze gdybym była znacznie młodsza od Ciebie i wyglądała tak jak dawniej, zaryzykowałabym choćby ze względu na dzieci, ale że wyglądam o 10 lat poważniej od Ciebie, a za parę lat już będę całkiem stara, a Ty w kwiecie sił, to albo mnię zostawisz jeszcze $\mathrm{z}$ dwojgiem małych dzieci, albo kochankę do domu mi sprowadzisz, albo mi tak dasz odczuć, że jestem Ci kulą u nogi, że życie moje będzie nie do wytrzymania ${ }^{141}$.

Przyznała się wreszcie Tadeuszowi, że w rzeczywistości ma więcej lat niż mu wcześniej, w czasie wojny, mówiła ${ }^{142}$. Wyobrażając sobie własną przedwczesną śmierć, zastanawiała się, czy przyszła macocha, którą Tadeusz po śmierci Fajgi by poślubił, nie skrzywdzi Adama i Ity ${ }^{143}$.

${ }^{137}$ Ibidem, List Fajgi Ginsberg do Tadeusza Kobyłki, Schirmeck, 15 I 1947 r.

${ }^{138}$ Ibidem, List Fajgi Ginsberg do Tadeusza Kobyłki, Marsylia, 8 VII 1947 r. W ostatnim liście do męża, wysłanym już z Tel Awiwu, powróciła do sprawy jego oskarżeń: „Nie jest tak, jak piszesz, że gwałtem go obrzezano. Jego nieobrzezanie mogli najwyżej nie tolerować i zażądać, bym wyjechała, do Polski. Ale jak się zdecydowałam jechać dalej, to nie miałam potrzeby zwlekać" (ibidem, List Fajgi Ginsburg do Tadeusza Kobyłki, Tel Awiw, 1 XII 1947 r.).

${ }^{139}$ Ibidem, List Fajgi Ginsberg do Tadeusza Kobyłki, 10 III 1947 r.

${ }^{140}$ Ibidem, List Fajgi Ginsberg do Tadeusza Kobyłki, 1 IV 1947 r.

${ }^{141}$ Ibidem, List Fajgi Ginsberg do Tadeusza Kobyłki, Marsylia, 8 VII 1947 r.

142 „Jeden tylko grzech mam na sumieniu, wprawdzie dałam Ci w niejednym liście do zrozumienia, że jestem od Ciebie starsza, nie musisz mi wierzyć. Poinformuj się w urzędzie metrykalnym w Rymanowie, ile mam lat, a wtedy może zrozumiesz, że jestem od Ciebie starsza. Wiesz, że mam rację, natura przecież robi swoje i wtedy kiedyś sam siebie zapytasz - po co mi to było - i na co mi to było" (ibidem, List Fajgi Ginsberg do Tadeusza Kobyłki, Strasburg, styczeń 1947 r.).

${ }^{143}$ Ibidem, List Fajgi Ginsberg do Tadeusza Kobyłki, Schirmeck, 10 XI 1946 r.; ibidem, List Fajgi Ginsberg do Tadeusza Kobyłki, Schirmeck, styczeń 1947 r.; ibidem, List Fajgi Ginsberg do Tadeusza Kobyłki, Marsylia, 8 VII 1947 r. 
Położenie Fajgi było trudne nie tylko ze względu na niepewność jutra i poczucie osamotnienia, lecz także zarzuty Kobyłki i być może strach przed ich ewentualnymi konsekwencjami. W liście z listopada 1946 r. ganiła Tadeusza: „Dajesz się unosić bujnej fantazji, chcesz się kłócić z całym światem” ${ }^{144}$. Zapewne starała się w ten sposób odpowiedzieć na jego oskarżenia pod adresem organizacji żydowskich, które obwiniał o wyjazd Fajgi i dzieci. Tłumaczyła mężowi, że nie było $w$ tym intrygi i decyzję podjęła sama ${ }^{145}$. Fajga jeszcze wielokrotnie w swoich listach podkreślała, że nikt na nią nie naciskał, by opuściła męża, że nie znajdowała się pod niczyim wpływem. Co więcej, kiedy zastanawiała się nad powrotem do Polski, zrozumiała, że Tadeusz wcale sobie tego nie życzy, skoro woli w końcu sam wyemigrować do Palestyny. Twierdziła, że pomogło jej to $\mathrm{w}$ podjęciu decyzji ${ }^{146}$. Starała się przedstawić rozpad ich związku jako wydarzenie bez kontekstu politycznego, pytając retorycznie: „Czyż jesteśmy jedynym małżeństwem, które się rozchodzi?"147. Fajga przypominała również mężowi, że zgodził się na jej emigrację, sam zaś w ostatniej chwili zrezygnował z przyłączenia się do niej i dzieci ${ }^{148}$. Choć podkreślała własną sprawczość w odniesieniu do decyzji o wyjeździe z Polski, zwracała uwagę na tradycyjny układ sił w ich związku - na przewagę męża pod każdym względem. Dlatego też wypominała Tadeuszowi niegodny mężczyzny zwyczaj winienia jej - owej „słabszej” strony w związku: „Zawsze, o ile Ci się coś nie udawało, ja byłam winna” ${ }^{149}$. W innym liście, napisanym w styczniu 1947 r., przypomniała mężowi upokorzenia, które znosiła, być może również w czasie okupacji, co mogło ją narazić na śmiertelne niebezpieczeństwo: „Wiesz dobrze, że gdy nie raz słyszałam «wynoś się» i zbierałam płaszcz, by pójść i więcej nie wrócić, stawało mi przed oczami dziecko, przez które byłam do Ciebie mocno przywiązana, i tylko przez wzgląd na dziecko znosiłam takie traktowanie”. We Francji dopiero zrozumiała, że była „gorzej traktowana od służącej” i że nie ma już siły więcej tego znosić, „stale płakać, stale spazmować"150. W jednym ze swoich ostatnich listów, wysłanym z Marsylii w lipcu 1947 r., prosiła męża o zrozumienie: „Staraj się choć raz w życiu mnię zrozumieć, bo gdybyś mnię [sic!] rozumiał, nie byłbyś mnię w ten sposób traktował. Chciałam Ci być wszystkim, byłam Ci niczym. Czy Ty sobie zdajesz sprawę,

${ }^{144}$ Ibidem, List Fajgi Ginsberg do Tadeusza Kobyłki, Schirmeck, 10 XI 1946 r.

${ }^{145}$ Ibidem. W swoim ostatnim liście odpowiedziała zapewne na zarzuty męża, przyznała bowiem: „Ten siak, ów inaczej, przecież jak sam piszesz, nienawiść rasowa jest silna”, odnosząc się zapewne do wypowiedzi na temat Tadeusza lub ich wspólnego wyjazdu (USHMM, Itta Keller Ben-Haiem Collection, 2007.129.1, List Fajgi Ginsberg do Tadeusza Kobyłki, Tel Awiw, 1 XII 1947 r.).

${ }^{146}$ Ibidem, List Fajgi Ginsberg do Tadeusza Kobyłki, Marsylia, 8 VII 1947 r.

${ }^{147}$ Ibidem, List Fajgi Ginsberg do Tadeusza Kobyłki, Strasburg, styczeń 1947 r.

${ }^{148}$ Ibidem, List Fajgi Ginsberg do Tadeusza Kobyłki, Schirmeck, 15 I 1947 r.

149 Ibidem.

${ }^{150}$ USHMM, Itta Keller Ben-Haiem Collection, 2007.129.1, List Fajgi Ginsberg do Tadeusza Kobyłki, Strasburg, styczeń 1947 r. 
co to znaczy dla kobiety czuć się u swego męża na łasce?"151. Przygotowując siebie i Tadeusza na ostateczne rozstanie, zapewniała, że będzie miał jeszcze dzieci i że ożeni się „z zaradną dziewczyną”. Prosiła go zarazem o zdjęcie - pamiątkę ${ }^{152}$. Wątek przyszłego małżeństwa Tadeusza wracał zresztą w innych listach Fajgi jako rodzaj obietnicy i zadośćuczynienia. $\mathrm{W}$ jednym $\mathrm{z}$ ostatnich zachowanych listów błagała Tadeusza:

o ile masz jeszcze dla mnie trochę sentymentu, to sobie powiedz: tak jest, tak musi być. Zrobisz krzyżyk nad przeszłością i zobaczysz, że będziesz szczęśliwy. Ożenisz się i wtedy możemy być dobrymi przyjaciółmi. Ale masz naturę dość zaciętą, mściwą, zaczniesz adwokatami się wysługiwać, a w tym wypadku nigdy się do Ciebie słówkiem nie odezwę. Mogłam i teraz zniknąć, i nie dać o sobie znaku życia ${ }^{153}$.

Fajga prosiła wreszcie Tadeusza, by dał „temu wszystkiemu spokój. Wiem, że dziecko kochasz i mnie może z daleka też trochę jeszcze lubisz, ale musisz sobie powiedzieć, że tak jak ja to zrobiłam, tak musi być". Zapewniała go, że znajdzie szczęście w nowym małżeństwie, a ona odwiedzi go „nawet z Ameryki” ${ }^{154}$. Obiecała wdzięczność, jeśli Tadeusz zostawi ją i dziecko w spokoju. W ostatnim liście, z grudnia 1947 r., opisała pierwsze dni, które spędziła już w Palestynie, gdzie czuła się „rozkręcona, zdegustowana, zmęczona” 155 . Po raz kolejny próbowała odwieść Tadeusza od interpretowania ich rozstania w kategoriach politycznych, ale teraz starała się ich osobisty dramat bagatelizować: „Robisz się bohaterem romantycznej powieści”156. Tłumaczyła, że choć ich sytuacja była skomplikowana, a otoczenie nie odnosiło się do ich związku życzliwie, to rozpad małżeństwa był osobisty i banalny, i oboje mieli w nim swój udział. Stwierdziła: „Ale z tego musimy sobie zdać dokładnie sprawę, że gdyby współżycie nasze było oparte na wzajemnym zrozumieniu i bylibyśmy ze sobą szczęśliwi, nie byłbyś mię samą z dwojgiem małych dzieci puścił w świat i ja nie byłabym mogła się zdecydować iść sama na tułaczkę". Fajga tak uzasadniała Tadeuszowi, dlaczego nie zdecydowała się na powrót do Polski: „bo bałam się nie Ciebie, lecz natury Twojej gderliwej, zjadliwej, która mnię nieraz do takiego stanu rozpaczy doprowadzała, że byłam w stanie samobójstwo popełnić. Jestem 100 pr[ocent] pewna, że jeszcze rok lub dwa, a byłabym skończyła na Kulparkowie albo suchoty dostała". Wreszcie do jej decyzji przyczyniła się świadomość, że przestaje się mężowi podobać: „Było mi tak strasznie przykro, gdy mi powiedziałeś, że wyglądam na bardzo

${ }^{151}$ Ibidem, List Fajgi Ginsberg do Tadeusza Kobyłki, Marsylia, 8 VII 1947 r.

152 Ibidem, List Fajgi Ginsberg do Tadeusza Kobyłki, 1 IV 1947 r. List jednak podpisała swoim „aryjskim” imieniem Maria.

${ }^{153}$ Ibidem, List Fajgi Ginsberg do Tadeusza Kobyłki, Strasburg, styczeń 1947 r.; podpisała go „Twoja przyjaciółka Fanka Ginzberg”.

${ }^{154}$ Ibidem, List Fajgi Ginsberg do Tadeusza Kobyłki, Strasburg, styczeń 1947 r.

155 Ibidem, List Fajgi Ginsberg do Tadeusza Kobyłki, Tel Awiw, 1 XII 1947 r.

${ }^{156}$ Ibidem. 
zniszczoną, że wyglądam jak matrona, że ten i ów powiedział, że wyglądam poważnie. Jaki koniec by mnię czekał, o tym Ci wyżej pisałam". Na swój wygląd zrzucała również winę za rosnące w ich małżeństwie napięcia: „Może i dlatego działałam na Ciebie jak osławiona czerwona płachta na byka. Zawsze stawałeś się w mojej obecności zły, zdenerwowany. Mężczyzna lubi, gdy kobieta jest ładnie ubrana i dobrze wygląda". Gdyby nawet Tadeusz miał do Palestyny przyjechać, trudne warunki życia sprawiłyby nieuchronnie, że winiłby Fajgę o wszystko, a ona - jak podkreślała - nie miała „sił do spazmów i bicia się w głowę. Suchy kawałek chleba jeść, byle być razem - jest to bardzo mądrym przysłowiem, ale u nas, przy Twej naturze, nie może mieć zastosowania. Choćbyś sobie sto razy powiedział, że będziesz inny - natury zmienić nie można". Przypominając mu, że na żądania finansowe w sprawie Ity było już za późno i że zwyczajowo to w jej rękach jako matki była decyzja o losie Adama, prosiła jeszcze raz, by nie komplikował sytuacji, wyjechał z Bytomia i ułożył sobie życie na nowo. „Nie ma sensu, byśmy nawiązywali korespondencję. Ale napisz mi tylko, że nie masz do mnie żalu ani pretensji i że jesteśmy wolni”157.

Listy Fajgi wyrażają jej wdzięczność, a zarazem poczucie głębokiego uwikłania. Niewykluczone jednak, że pisząc do męża, przedstawiała swoje uczucia w taki sposób, by przekonać go, że powinien jej pozwolić na rozpoczęcie samodzielnego życia. Schlebiając mu, próbowała złagodzić jego złość. Nawet jej powtarzające się aluzje do zaawansowanego wieku, mniej atrakcyjnego wyglądu i lęku, że może już nie podobać się mężowi, miały upewnić Tadeusza, że to on w istocie podjął decyzję o rozstaniu, bo Fajga nie była już w jego oczach atrakcyjna, że to jego brak uczuć dla żony miał sprawczy charakter. Co zaskakujące, Fajga prawie nie wspominała o swoich doświadczeniach w czasie wojny. Skupiała się raczej na bieżących problemach małżeńskich i obawach przed nieszczęśliwą dla obojga wspólną przyszłością. Tylko między wierszami można odczytać w jej listach aluzje do cierpienia, które było jej udziałem w czasie okupacji i które wiązało się z jej całkowitą zależnością od Tadeusza. Być może dopiero w ostatnim liście najbardziej jednoznacznie odniosła się do roli Tadeusza w okupacyjnym Lwowie:

Dużo mi dałeś, bo życie, lecz o ile mnie kochałeś, jest to naturalny objaw. Byłam Ci żoną szczerze oddaną. Nie zdradzałam Cię nawet myślami, jednak tak musi być. 0 ile Ci może przykrość sprawiam, nie gniewaj się na mnie. Inaczej być nie może. Będziesz mi kiedyś wdzięczny, że Ci nie pomagam do kroku, który by był dla Ciebie szaleństwem, a dla mnie męką. Bądź zdrów i myśl o mnie zawsze dobrze ${ }^{158}$.

${ }^{157}$ Ibidem.

${ }^{158}$ Ibidem. 


\section{Podsumowanie}

Korespondencja Fajgi i Tadeusza odzwierciedla skomplikowane zależności między ocalałymi Żydami a tymi, którzy odegrali kluczową rolę w ich przetrwaniu. Ocalali musieli odpowiedzieć sobie na pytania o najbliższą przyszłość, wizję nowego życia osobistego i społeczności, której byli częścią. Próbowali żyć z ciężarem poniesionych strat: poszukiwali krewnych i budowali nowe wspólnoty, niektórzy podejmowali próby odzyskania mienia i wymierzenia sprawiedliwości zbrodniarzom uczestniczącym w Zagładzie i tym, którzy ich skrzywdzili pod okupacją niemiecką. Listy Fajgi wyrażają traumę Żydów, którzy przeżyli Holokaust. Ukazują również skutki powojennych wyborów dla życia ocalałych i tych, którzy pomagali. Omówiona korespondencja ujawnia, jak odmienna była wizja ich związku i rozstania. Różnica wynikała częściowo z różnych odbiorców: Fajga pisała osobiste listy do męża, podczas gdy listy Tadeusza trafiały do rozmaitych instytucji żydowskich i polskich i miały bardziej oficjalny charakter. W listach tych wyraźnie wybrzmiewał jego gniew na „Żydów”, których obwiniał za rozpad jego rodziny, ale przenika je również poczucie zagrożenia powojennym antysemityzmem w Polsce, gdyż sam go doświadczał po wyjeździe Fajgi.

Chociaż wymiana listów między Fajgą a Tadeuszem jest pełna niedopowiedzeń, wskazuje, że ocalali z Zagłady musieli stawić czoła złożonym problemom i podejmować trudne decyzje osobiste. Ten aspekt powojennego krajobrazu nie został dotąd obszernie omówiony w dyskursie akademickim. Można w tej korespondencji odnaleźć ślady nacisków, jakim podlegali Żydzi, którzy pozostali przy swojej nieżydowskiej tożsamości ${ }^{159}$. Czy powinni trwać w związkach opartych na wspólnych traumatycznych doświadczeniach i wzmocnionych poczuciem zależności i wdzięczności wobec ludzi, którzy odegrali kluczową rolę w ich ocaleniu? Związki te często przełamywały przedwojenne podziały klasowe, wychodziły poza tradycyjne żydowskie i chrześcijańskie normy religijne i kulturowe.

Chociaż nie mamy wglądu w najbardziej intymne przemyślenia bohaterów, to wciąż możemy czerpać z zeznań, pamiętników, wspomnień i wywiadów ustnych, aby dowiedzieć się, jak radzili sobie z pytaniami dotyczącymi ich wojennych relacji już po wyzwoleniu. Fajga często przypominała Tadeuszowi o dzielących ich różnicy wieku i charakterów, ostatecznie wyrażając wdzięczność, ale jednocześnie przyznając, że połączyła ich dopiero wojna. Ich korespondencja problematyzuje kategorię tożsamości, obalając stereotypy „nacjonalistycznego Polaka” i „,́́wiadomego siebie Żyda”. Obie te kategorie okazują się zbyt dużym uproszczeniem, które nie oddaje złożoności relacji, zwłaszcza tej zainicjowanej podczas Zagłady.

W kontekście więzi, które rozwinęły się w czasie wojny, pojawia się jednak pytanie, w jakiej mierze było to prawdziwe małżeństwo. Czy organizacje żydow-

${ }^{159}$ Zob. Natalia Aleksiun, Uneasy Bonds. On Jews in Hiding and the Making of Surrogate Families [w:] Jewish and Romani Families in the Holocaust and Its Aftermath, red. Eliyana R. Adler, Kateřina Čapková, New Brunswick, NJ: Rutgers University Press, 2020, s. 85-99. 
skie i rabini (w tym szwagier Fajgi w Palestynie) byli zaangażowani w odzyskanie jej i dzieci? Czy rzeczywiście spodziewała się, że jej mąż pojedzie za nimi do Palestyny? A może uciekła przed trudnym małżeństwem? Czy nie mogła już dłużej negocjować swojego miejsca w związku będącym wynikiem okupacyjnej zależności? Zanim Polska Rzeczpospolita Ludowa zniosła ograniczenia religijne i klasowe dla „małżeństw mieszanych”, żydowskie próby przetrwania stworzyły przestrzeń dla tych nieprawdopodobnych związków, czego dowodem może być właśnie historia Fajgi i Tadeusza.

\section{BIBLIOGRAFIA}

\section{Źródła archiwalne}

\section{Archiwum Yad Vashem (AYV)}

M.31.2/5604

The Central Database of Shoah Victims' Names, Shlomo Keller, https://yvng.yadvashem.org/nameDetails.html?language=en\&itemId=3936984\&ind=7

Archiwum Żydowskiego Instytutu Historycznego (AŻIH)

Centralna Kartoteka Żydów w Polsce 1945-1951, 303/V/425, 1755/79930 $301 / 6612$

United States Holocaust Memorial Museum (USHMM)

Itta Keller Ben-Haiem Collection, 2007.129.1

\section{Literatura przedmiotu}

Aleksiun Natalia, Dokq̨d dalej? Ruch syjonistyczny w Polsce 1944-1950, Warszawa: Trio, 2002.

Aleksiun Natalia, Uneasy Bonds. On Jews in Hiding and the Making of Surrogate Families [w:] Jewish and Romani Families in the Holocaust and Its Aftermath, red. Eliyana R. Adler, Kateřina Čapková, New Brunswick, NJ: Rutgers University Press, 2020.

Arieh J. Kochavi, The Struggle against Jewish Immigration to Palestine, „Middle Eastern Studies" 1998, t. 34, nr 3.

Avinoam Patt, Finding Home and Homeland. Jewish Youth and Zionism in the Aftermath of the Holocaust, Detroit, MI: Wayne State University Press, 2009.

Bikont Anna, Sendlerowa. W ukryciu, Wołowiec: Czarne, 2017.

Bogner Nahum, At the Mercy of Strangers. The Rescue of Jewish Children with Assumed Identities in Poland, Jerusalem: Yad Vashem, 2009.

Cichopek-Gajraj Anna, Beyond Violence. Jewish Survivors in Poland and Slovakia, 19441948, Cambridge: Cambridge University Press, 2014.

Cohen Boaz, Survivor Caregivers and Child Survivors. Rebuilding Lives and the Home in the Postwar Period, „Holocaust and Genocide Studies” 2018, t. 32, nr 1.

Engel David, The Reconstruction of Jewish Communal Institutions in Postwar Poland. The Origins of the Central Committee of Polish Jews, 1944-1945, „East European Politics and Societies" 1996, t. 10, nr 1.

Friedla Katharina, „A Naye Yidishe Heym in Nidershlezye”. Polnische Shoah-Überlebende in Wrocław (1945-1949). Eine Fallstudie, „S:I.M.O.N. Shoah: Intervention. Methods. Documentation" 2014, t. 1, nr 1.

Friedla Katharina, Strategie przetrwania i udzielanie pomocy żydowskim partnerom w małżeństwach mieszanych we Wrocławiu i Hamburgu. Studium kilku przypadków, „Zagłada Żydów. Studia i Materiały” 2015, nr 11. 
Grabowski Jan, Ratowanie Żydów za pieniq̨dze: przemysł pomocy, „Zagłada Żydów. Studia i Materiały" 2008, nr 4.

Grabowski Jan, Rescue for Money. Paid Helpers in Poland, 1939-1945, Jerusalem: Yad Vashem, 2008.

Gross Jan Tomasz, Strach. Antysemityzm w Polsce tuż po wojnie. Historia moralnej zapaści, Kraków: Znak, 2008.

Gusarov Katya, Sexual Barter and Jewish Women's Efforts to Save Their Lives. Accounts from the Righteous among the Nations Archives, "German History”, 25 V 2020, https://doi.org/10.1093/gerhis/ghaa034.

Hájková Anna, Sexual Barter in Times of Genocide. Negotiating the Sexual Economy of the Theresienstadt Ghetto, „Signs” 2013, t. 38, nr 3.

Kamil Kijek, Aliens in the Lands of the Piasts. The Polonization of Lower Silesia and Its Jewish Community in the Years 1945-1950 [w:] Jews and Germans in Eastern Europe. Shared and Comparative Histories, red. Tobias Grill, Berlin: De Gruyter, 2018.

Kaplan Marion A., Between Dignity and Despair. Jewish Life in Nazi Germany, New YorkOxford: Oxford University Press, 1998.

Keller Itta Benhaiem, U-welibi homa, Jeruszalaim: Yad Vashem, 2009.

Keller Itta, Stary Sambor and Lviv, Ukraine, http://missing-identity.net/itta-keller-starysambor-and-lviv-ukraine.

Meyer Beate, „Jüdische Mischlinge”. Rassenpolitik und Verfolgungserfahrung 1933-1945, Hamburg: Dölling und Galitz Verlag, 1999.

Michlic Joanna B., Piętno Zagłady. Wojenna i powojenna historia oraz pamięć żydowskich dzieci ocalałych w Polsce, Warszawa: Żydowski Instytut Historyczny, 2020.

Michlic Joanna B., "The War Began for Me after the War." Jewish Children in Poland, 1945-49 [w:] The Routledge History of the Holocaust, red. Jonathan C. Friedman, London: Routledge, 2011.

Nachmany-Gafny Emunah, Dividing Hearts. The Removal of Jewish Children from Gentile Families in Poland in the Immediate Post-Holocaust Years, Jerusalem: Yad Vashem, 2009.

Schrafstetter Susanna, Flucht und Versteck. Untergetauchte Juden in München. Verfolgungserfahrung und Nachkriegsalltag, Göttingen: Wallstein, 2015.

Seidman Naomi, Sarah Schenirer and the Bais Yaakov Movement. A Revolution in the Name of Tradition, Liverpool: The Littman Library of Jewish Civilization, 2019.

Shlomi Hana, The Communist Caucus in the Central Committee of Jews in Poland, November 1944-February 1947, „Gal-Ed. On the History of the Jews in Poland” 1993, nr 13.

Slucki David, The International Jewish Labor Bund after 1945. Toward a Global History, New Brunswick, NJ: Rutgers University Press, 2012.

Szaynok Bożena, Bund i komuniści żydowscy w Polsce po 1945 r. [w:] Bund. 100 lat historii 1897-1997, red. Feliks Tych, Jürgen Hensel, Warszawa: Volumen, 2000.

Szaynok Bożena, Z historiq i Moskwq w tle. Polska a Izrael 1944-1968, Warszawa: IPN, 2007.

Tokarska-Bakir Joanna, Pod klątwą. Społeczny portret pogromu kieleckiego, t. 1-2, Warszawa: Czarna Owca, 2018.

Utz Raphael, Making Love and Make-Belief: Male Sexual Barter in Dov Freiberg's "To Survive Sobibor”, „Autobiografia. Literatura, kultura, media” 2010, nr 1 (14).

Wieczorek Paweł, „Sztuczny antysemityzm”. Antyżydowskie wystąienia na Dolnym Śląsku w 1956 roku [w:] Przemoc antyżydowska i konteksty akcji pogromowych na ziemiach polskich w XX wieku, red. Konrad Zieliński, Kamil Kijek, Lublin: Wyd. UMCS, 2016.

Wywiad z rabinem Jaakowem Edelsteinem przeprowadzony przez Cwiego Jaakowwsona, 23 III 2017, http://beinenu.com/sites/default/files/alonim/176_22_23_77.pdf. 